KUZNIK, Anna; VERD, Joan Miquel; OLALLA-SOLER, Christian (2016) "Mixed methods, mixed tools. The use of computer software for integrated qualitative and quantitative analysis", Journal of Research Design and Statistics in Linguistics and Communication Science [JRDS], 3.1. (December 2016), pp. 76-109, DOI: 10.1558/irds.32360 , URI: https://journals.equinoxpub.com/index.php/JRDS/article/view/32360 , special issue "Mixed Methods" guest-edited by Anna Kuznik and Joan Miquel Verd, ISSN: 2052-417X (Print), 20524188 (Online)

[page 76 in published version:]

\title{
Mixed methods, mixed tools. The use of computer software for integrated qualitative and quantitative analysis
}

Anna Kuznik (Zakład Translatologii, Instytut Filologii Romańskiej, Uniwersytet Wrocławski, Anna.Kuznik@uwr.edu.pl )

Joan Miquel Verd (Centre d'Estudis Sociològics sobre la Vida Quotidiana i el Treball (QUIT), Institut d'Estudis del Treball (IET), Department of Sociology, Universitat Autònoma de Barcelona, JoanMiquel.Verd@uab.cat )

Christian Olalla-Soler (Departament de Traducció, d'Interpretació i d'Estudis de 1’Àsia Oriental, Universitat Autònoma de Barcelona, Christian.Olalla@uab.cat )

\begin{abstract}
We report on how two different software programs (Camtasia and EdEt) were used in the process of data conversion from qualitative to quantitative format. This process, known as quantitative translation of data, can be considered a specific kind of mixed methods analysis. We show the methodological and technical limits of the programs and the possibilities they offer for quantitative translation. We reflect on the role these software packages played in the different stages of data collection and data analysis of the studies described. Finally, we delve into the methodological and epistemological criticisms of the use of software for qualitative data analysis, concluding that they are meaningful warnings to avoid a misuse of software but do not apply when researchers adopt an interpretive approach in which they actively participate in the development and testing of categories.
\end{abstract}

Keywords: Camtasia, EdEt, Mixed Methods, Translation, Translation Studies, Quantitive Translation

\section{Introduction}

The use of the term mixed methods to describe the combination of quantitative and qualitative information in research is not without controversy. The first question that arises is whether it is an innovative approach in social research or

[page 77 in published version:]

is simply a new 'trademark' for naming a methodological practice that is as old as social 
KUZNIK, Anna; VERD, Joan Miquel; OLALLA-SOLER, Christian (2016) "Mixed methods, mixed tools. The use of computer software for integrated qualitative and quantitative analysis", Journal of Research Design and Statistics in Linguistics and Communication Science [JRDS], 3.1. (December 2016), pp. 76-109, DOI: 10.1558/irds.32360 , URI: https://journals.equinoxpub.com/index.php/JRDS/article/view/32360 , special issue "Mixed Methods" guest-edited by Anna Kuznik and Joan Miquel Verd, ISSN: 2052-417X (Print), 20524188 (Online)

sciences themselves. The term mixed methods was coined by a movement that appeared in the late 1980s (Fàbregues, 2015), with clear roots in the United States, and that used practices of methodological combination that had existed much earlier. It was an interdisciplinary movement that emerged in areas of applied research, such as evaluation or education. This very specific geographical origin of its main leaders and the applied nature of the disciplines where the initial forerunners of the movement worked explain why, at least initially, the focus was much more on procedural and design issues than on epistemological and ontological questions. This was the result of the objective of formalizing and systematizing most of the possibilities of combination of quantitative and qualitative data, in sharp contrast to previous methodological literature oriented toward paradigmatic debates (Koetting, 1984, Lincoln and Guba, 1985).

On the other hand, the development and increasingly frequent use of computerassisted qualitative data analyses (CAQDAS) has also helped turn the debate on the integration of quantitative and qualitative data toward more technical and procedural issues. It is undeniable that the development of software oriented toward qualitative analysis and the latest developments in software inherently designed for mixed methods purposes (Bazeley, 2010) triggered a new array of technical and methodological reflections.

This paper does not deny the need to deal with ontological and epistemological issues when the integration of quantitative and qualitative data is addressed (Blaikie, 1991; Bericat, 1998), but focuses on more purely methodological and technical issues. In fact, the purpose of the paper is to show that the use of software facilitates a very specific type of data integration, that of data conversion, and more specifically that of quantitative translation (Boyatzis, 1998). In other words, the paper raises the question of how and to what extent computer software for qualitative data collection and analysis can help the conversion and subsequent analysis of information originally collected in a qualitative format by means of quantitative tools.

The rationale for this kind of data conversion design is not different from that of other particular varieties of mixed methods designs: the combination of qualitative and quantitative versions of data produces a more complete view of the phenomenon under study. And this more complete view is achieved by means of an efficiency principle (Verd and López, 2008), i.e. the amount of information needed for a given level of explanation is minimized (economy of data).

The role played by software in this process of data conversion will be highlighted by focusing on the different ways in which two software programs - one for 
KUZNIK, Anna; VERD, Joan Miquel; OLALLA-SOLER, Christian (2016) "Mixed methods, mixed tools. The use of computer software for integrated qualitative and quantitative analysis", Journal of Research Design and Statistics in Linguistics and Communication Science [JRDS], 3.1. (December 2016), pp. 76-109, DOI: 10.1558/irds.32360 , URI: https://journals.equinoxpub.com/index.php/JRDS/article/view/32360 , special issue "Mixed Methods" guest-edited by Anna Kuznik and Joan Miquel Verd, ISSN: 2052-417X (Print), 20524188 (Online)

qualitative data collection and one for qualitative data analysis - have been used in the context of translation studies research. The two programs

[page 78 in published version:]

chosen are Camtasia, a software for screen recording that is not specifically intended for research objectives, and $E d E t$, a software for qualitative data analysis that was initially designed for learning purposes. ${ }^{\mathrm{i}}$ The use of Camtasia will be exemplified with an experimental study into translation competence and translation competence acquisition and the use of EdEt with a study on foreign language acquisition and the current needs of the labor market. The two programs are presented following the logical sequence in which they would be used in a research process: first data collection, and second data analysis, corresponding to Camtasia and EdEt, respectively.

As these two programs were not designed for the purpose of data integration, we explain at length how they are used by the authors, so that other researchers can learn from the examples.

Apart from this introduction (section 1), the paper is divided into four main sections. In section 2 the process of quantitative translation is described, and the role of software in this process is addressed. In sections 3 and 4 the programs Camtasia and $E d E t$ are introduced, together with their uses in different research projects in which the authors of this article have taken part. Finally, in section 5, the conclusions are presented in the form of a methodological reflection on the role played by software in the process of quantitative translation.

\section{Quantitative translation and the use of computer software}

Quantitative translation (Boyatzis, 1998:129), also known as the 'quantitizing strategy' (Tashakkori and Teddlie, 1998:126; Onwuegbuzie and Teddlie, 2003:355) is a specific variety of data conversion ${ }^{\mathrm{ii}}$ that transforms data from a qualitative form into a quantitative one, involving the reduction of 'themes or codes to numeric information, such as dichotomous categories' (Creswell and Plano-Clark, 2011:231). This procedure should not be mistaken for quantitative (and automated) text analysis in the vein of 'classic' content analysis (Berelson, 1971; Weber, 1985), because in quantitative content analysis there is no (human) interpretation of the data. 
KUZNIK, Anna; VERD, Joan Miquel; OLALLA-SOLER, Christian (2016) "Mixed methods, mixed tools. The use of computer software for integrated qualitative and quantitative analysis", Journal of Research Design and Statistics in Linguistics and Communication Science [JRDS], 3.1. (December 2016), pp. 76-109, DOI: 10.1558/irds.32360 , URI: https://journals.equinoxpub.com/index.php/JRDS/article/view/32360 , special issue "Mixed Methods" guest-edited by Anna Kuznik and Joan Miquel Verd, ISSN: 2052-417X (Print), 20524188 (Online)

Although data conversion is not rare in social research (Fielding and Fielding, 2008), especially in its quantitizing version, clear and detailed explanations of the procedures for converting one form of data to another are much less frequent (Mertens, Bazeley, Bowleg, Fielding, Maxwell, Molina-Azorin and Niglas, 2016). This is not surprising, because data conversion is not of paramount importance in the methodological literature on mixed methods research. Indeed, among the many reasons offered by Creswell and Plano-Clark (2011:7--11) for using a mixed methods design in social research, there are none that could be directly applied to data conversion designs. The need to

[page 79 in published version:]

enhance a primary method by using a second method is the closest to the reasons listed by Creswell and Plano-Clark (2011:10). However, data conversion does not imply the use of different methods of data collection, but only different methods of data analysis, as the different kinds of data used are collected with a single method.

The advantage of quantitative translation is that the initial stage of analysis consists of a qualitative coding of data, which implies that codes are interpretively generated taking into account the context and the syntactic and semantic characteristics of qualitative data. This strategy prevents a loss of information and produces sounder and richer categories, because the researcher does not have to anticipate the codes to be used in the analysis. However Miles and Huberman (1994:214) note that quantitative translation 'is not an operation to be taken lightly. Rather, it should be a self-conscious procedure with clear decision rules'.

In this article we contend that the use of software during data collection or data analysis improves the process of quantitative translation. Bazeley has identified perfectly its advantages in the analysis of textual data:

With the use of software to generate codes for statistical analysis from qualitative material, text associated with those codes is retained in a readily accessible way. This assists interpretation of patterns during the process of analysis, validation of conclusions through checking back against the qualitative data, and initiation of further qualitative analyses or re-analyses. (Bazeley, 2010:443)

We go a little further and advocate the use of software also in the stage of data collection, not only for textual data but also for any kind of qualitative data. We do not 
KUZNIK, Anna; VERD, Joan Miquel; OLALLA-SOLER, Christian (2016) "Mixed methods, mixed tools. The use of computer software for integrated qualitative and quantitative analysis", Journal of Research Design and Statistics in Linguistics and Communication Science [JRDS], 3.1. (December 2016), pp. 76-109, DOI: 10.1558/irds.32360 , URI: https://journals.equinoxpub.com/index.php/JRDS/article/view/32360 , special issue "Mixed Methods" guest-edited by Anna Kuznik and Joan Miquel Verd, ISSN: 2052-417X (Print), 20524188 (Online)

campaign for a direct quantitative analysis of qualitative data solely through the use of software (which could be suitable for some specific and very structured qualitative data), but rather for a more complex analysis in which a human analyst first interprets and categorizes the data, and then converts the codes into quantitative units. In this process, the use of software offers a range of advantages that will be presented and discussed in the following sections.

We wish to stress that there are no contradictions between the need for human interpreters to assign a meaning during the analysis of qualitative data and the use of computer programs to do so more quickly and transparently (Verd and Lozares, 2016:315--320). However, some researchers who believe at heart in the importance of interpretation are reluctant to use software (for instance, Denzin and Lincoln, 2011), so criticisms of any use of software in qualitative research still persist. These criticisms may be divided into methodological and epistemological ones. We present them briefly in order to provide an initial element of debate on this question and to frame the discussion that

[page 80 in published version:]

will be presented in the Conclusions section. These criticisms are not meaningless and should be taken as critical warnings.

Methodological criticisms:

- Absence of interpretation in the analysis: it is claimed that use of computers during the analysis prevents a comprehensive interpretation of the text.

- Loss of control by the analyst: it is claimed that control of the analysis procedure is relinquished to the embedded procedures in the software.

- Excessive formalization of the analysis: it is stated that software packages tend to overly formalize the analysis, thus losing the essence of qualitative analysis, which is the holistic and empathic interpretation of data.

Epistemological criticisms:

- The categories of analysis are forcibly imposed: it is stated that predefined categories and codes that force the interpretation of data are used.

- The extra-textual dimensions of data are left aside: it is stated that computers prevent the analyst from taking into account the contextual and social information that is relevant for the interpretation of texts.

- The role of the researcher as an 'active agent' in the analysis is hidden: it is claimed 
This is a post-print version of the following paper published online $24^{\text {th }}$ of February, 2017:

KUZNIK, Anna; VERD, Joan Miquel; OLALLA-SOLER, Christian (2016) "Mixed methods, mixed tools. The use of computer software for integrated qualitative and quantitative analysis", Journal of Research Design and Statistics in Linguistics and Communication Science [JRDS], 3.1. (December 2016), pp. 76-109, DOI: 10.1558/irds.32360 , URI: https://journals.equinoxpub.com/index.php/JRDS/article/view/32360 , special issue "Mixed Methods" guest-edited by Anna Kuznik and Joan Miquel Verd, ISSN: 2052-417X (Print), 20524188 (Online)

that, since there are no single interpretations in qualitative analysis, it is important to show how the researcher 'reads' the data, and that computer programs do not allow this to happen.

\section{Camtasia}

\subsection{General features and functions}

Camtasia Studio is a screen recording program which was first designed for purposes far removed from empirical research. The main aim was to offer a screen recording solution for creating video tutorials or presentations using screencasts. The program was first released in 2002 by TechSmith and the latest version (version 8.6.0) was released in 2012. It is released for both Windows and Macintosh operating systems, although the version for Macintosh was not released until June 2011 and the latest version is 2.10.6 (June 2016). It is proprietary and commercial software and is not open source.

Camtasia Studio contains two programs: Camtasia Recorder and Camtasia Studio editor. Before we present Camtasia Recorder, we will briefly present

[page 81 in published version:]

Camtasia Studio editor, which is not useful for extracting data from the recordings.

\subsubsection{Camtasia Studio editor}

This program is used to edit videos created with Camtasia Recorder (Figure 3.1.). It works similarly to other video editors: multimedia objects (video and audio) are dragged and placed in order in a timeline and transition effects can be added between videos. The program also includes some features specially designed for creating screencast presentations, such as an option to highlight specific sections of the recorded screen and the possibility of hiding or showing the cursor. 
KUZNIK, Anna; VERD, Joan Miquel; OLALLA-SOLER, Christian (2016) "Mixed methods, mixed tools. The use of computer software for integrated qualitative and quantitative analysis", Journal of Research Design and Statistics in Linguistics and Communication Science [JRDS], 3.1. (December 2016), pp. 76-109, DOI: 10.1558/irds.32360 , URI: https://journals.equinoxpub.com/index.php/JRDS/article/view/32360 , special issue "Mixed Methods" guest-edited by Anna Kuznik and Joan Miquel Verd, ISSN: 2052-417X (Print), 20524188 (Online)

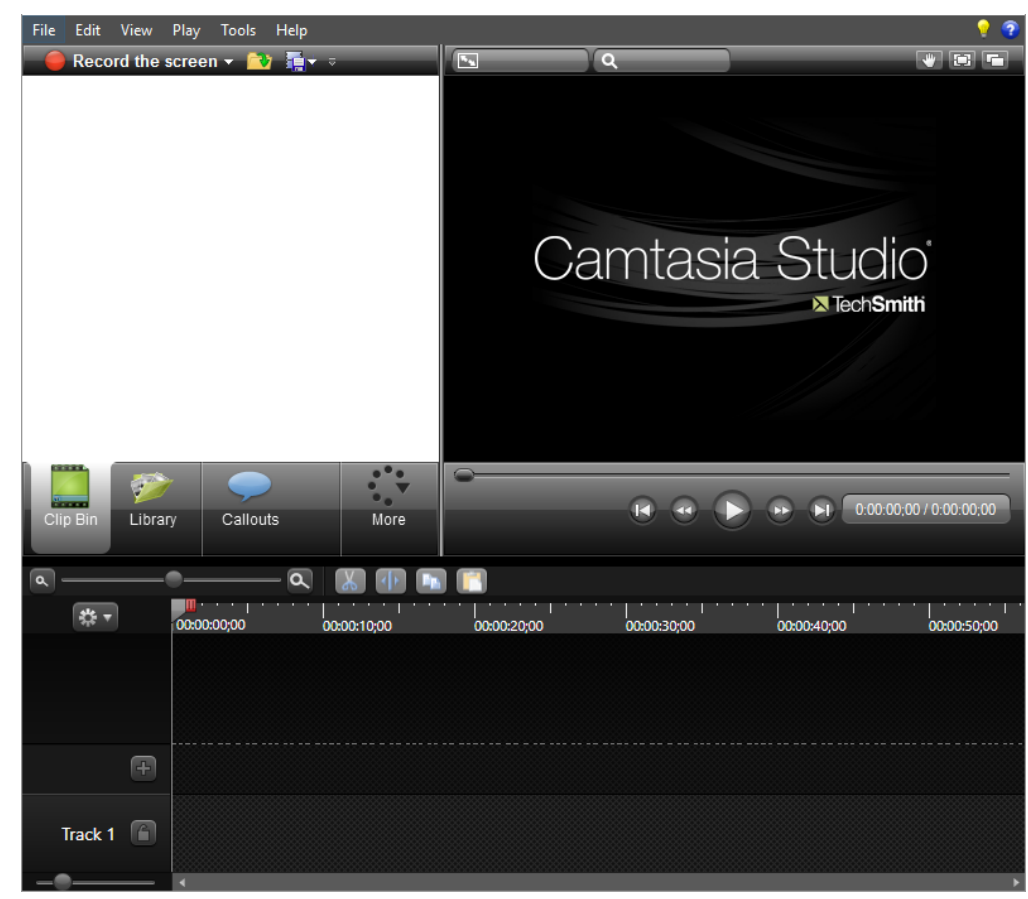

Figure 3.1. Main view of Camtasia Studio editor (v. 8.0) [page 81 in published version]

Although this program is able to read many different video formats (including WMV, WMA, AVI and MP4), some features are only available for the CAMREC format, which is one of the formats to which Camtasia Recorder can code the captured screencast. When the project is finished, it can be exported to many formats, including MPEG-2, WMV, AVI or Adobe Flash.

[page 82 in published version:]

\subsubsection{Camtasia Recorder}

This program is designed for screencasting and audio recording. This is an important feature for researchers who need to record both sources of data. Researchers may wish to record on-screen activity and use a think-aloud protocol to triangulate the data obtained. The program can even record video from a webcam, although this feature is not very useful if researchers prefer participants not to interact with Camtasia (Figure 3.2.). 
KUZNIK, Anna; VERD, Joan Miquel; OLALLA-SOLER, Christian (2016) "Mixed methods, mixed tools. The use of computer software for integrated qualitative and quantitative analysis", Journal of Research Design and Statistics in Linguistics and Communication Science [JRDS], 3.1. (December 2016), pp. 76-109, DOI: 10.1558/irds.32360 , URI: https://journals.equinoxpub.com/index.php/JRDS/article/view/32360 , special issue "Mixed Methods" guest-edited by Anna Kuznik and Joan Miquel Verd, ISSN: 2052-417X (Print), 20524188 (Online)

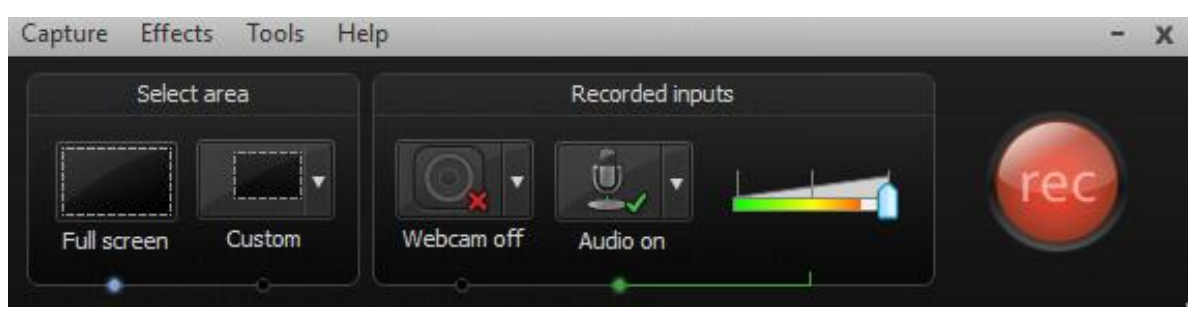

Figure 3.2. Main view of Camtasia Recorder (v. 8.0) [page 82 in published version]

This software is very flexible and allows the researcher to set many features according to his/her needs. The following are the most important ones:

- Researchers can define the area to be recorded. It is possible to record the whole screen, the screen of a single program or application that is running simultaneously with Camtasia, or any selected area of the screen. When more than one screen is used, Camtasia will record only one of them.

- In order to keep a high level of ecological validity of the study (Neunzig, 2000), researchers may prefer to keep Camtasia hidden during the whole recording. The program offers many settings that make this possible. Researchers may deactivate the glowing rectangle that shows the area being recorded, deactivate the screensaver while recording and hide the preview window when the recording is stopped. However, the most important feature is the possibility of minimizing the recording to the system tray, so the user will not see the Camtasia icon on the taskbar. Figure 3.3. shows the options that should be activated to hide Camtasia. Nonetheless, researchers should take into account the ethical issues that might arise from hiding the use of on-screen recording software.

- Researchers can define their own shortcuts to use the program. This is an important feature when researchers want to keep Camtasia hidden to the participant. Using complex shortcuts reduces the chances of having to stop the recording if participants use shortcuts during the tasks that are being recorded.

[page 83 in published version:] 
KUZNIK, Anna; VERD, Joan Miquel; OLALLA-SOLER, Christian (2016) "Mixed methods, mixed tools. The use of computer software for integrated qualitative and quantitative analysis", Journal of Research Design and Statistics in Linguistics and Communication Science [JRDS], 3.1. (December 2016), pp. 76-109, DOI: 10.1558/irds.32360 , URI: https://journals.equinoxpub.com/index.php/JRDS/article/view/32360 , special issue "Mixed Methods" guest-edited by Anna Kuznik and Joan Miquel Verd, ISSN: 2052-417X (Print), 20524188 (Online)

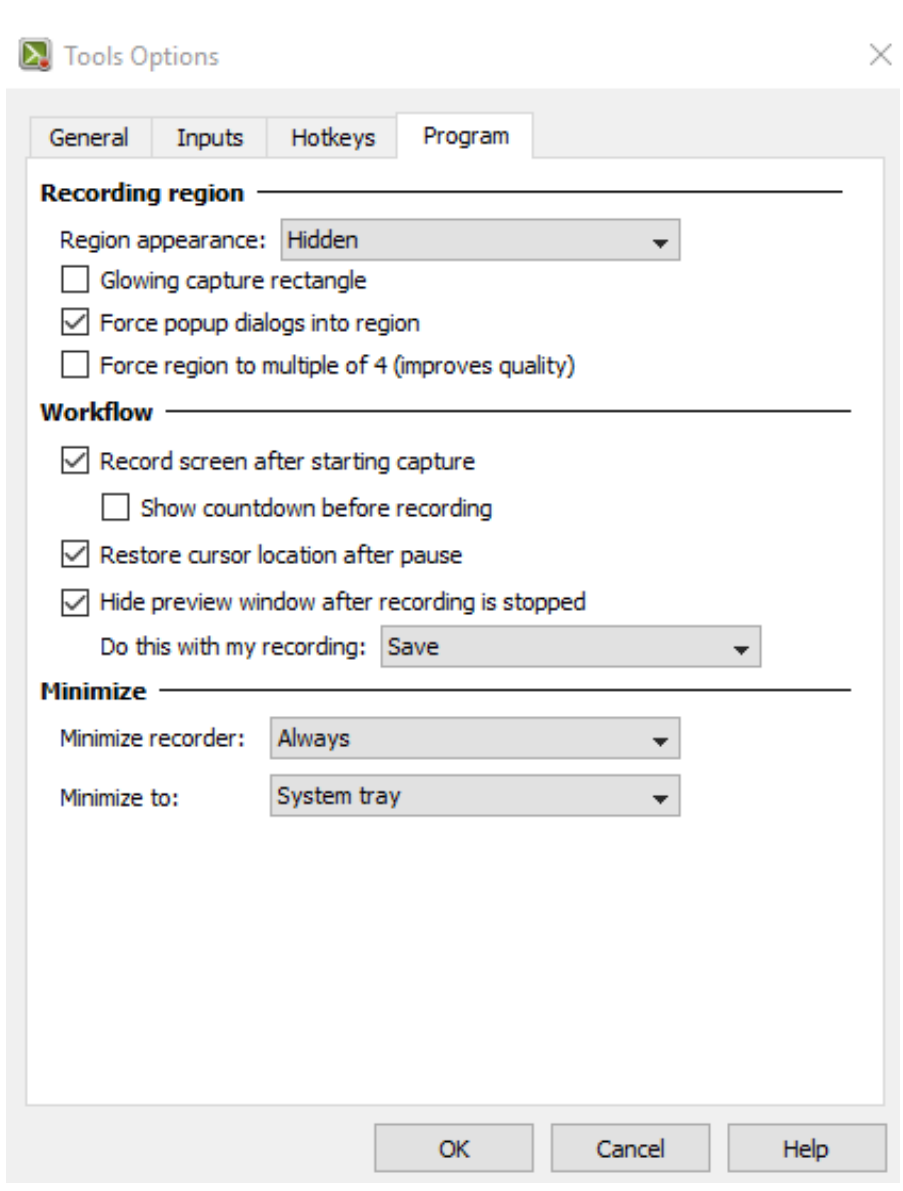

Figure 3.3. Setting Camtasia Recorder as hidden for the participant [page 83 in published version]

Once the recording is stopped, the program produces a file in CAMREC or AVI format. The first is only readable with Camtasia Studio editor and the second is compatible with almost all video players.

This program is able to record for a long time without reducing the computer speed. From the author's experience, Camtasia has been able to record on-screen activity for more than two hours without affecting the computer's performance (Kuznik \& Olalla-Soler in press; Olalla-Soler 2015).

\subsection{Examples of application of Camtasia in empirical studies}

On-screen recording software has been widely used in research on cognition in translation, on the translation process, and on translation competence.

[page 84 in published version:] 
KUZNIK, Anna; VERD, Joan Miquel; OLALLA-SOLER, Christian (2016) "Mixed methods, mixed tools. The use of computer software for integrated qualitative and quantitative analysis", Journal of Research Design and Statistics in Linguistics and Communication Science [JRDS], 3.1. (December 2016), pp. 76-109, DOI: 10.1558/irds.32360 , URI: https://journals.equinoxpub.com/index.php/JRDS/article/view/32360 , special issue "Mixed Methods" guest-edited by Anna Kuznik and Joan Miquel Verd, ISSN: 2052-417X (Print), 20524188 (Online)

Translation, Research, Empiricism and Cognition (TREC) is a network of more than 50 translation scholars united by their interest in empirical research and the investigation of the human translation process, especially with respect to cognition. ${ }^{\text {iii }}$ This network is an initiative of the Process of Acquisition of Translation Competence and Evaluation (PACTE) research group ${ }^{\text {iv }}$ financed by the Spanish Ministry of Economy, Industry and Competitiveness.

TREC members use on-screen recording software in their research for a variety of purposes but with a common argument in favour of its use: ecological validity. A major advantage of screen recording as a research tool is its relative preservation of ecological validity. Translators are not required to do anything they would otherwise not do while translating in their natural environments, and the program can be readily installed on any computer. The software runs unobtrusively in the background during task completion.

To date, screen recording has been used as a method for researching such phenomena as translator style, problem-solving in translation and revision tendencies (TREC, 2015b). In Table 1 we present the research projects carried out by TREC members in which on-screen recordings are used.

Table 1. TREC members' research projects in which on-screen recording software is used [pages 84-85 in published version]

\begin{tabular}{|l|l|l|l|}
\hline \multicolumn{1}{|c|}{$\begin{array}{c}\text { Project title and } \\
\text { research period }\end{array}$} & $\begin{array}{c}\text { Research group(s)/ } \\
\text { researcher(s) in charge }\end{array}$ & $\begin{array}{c}\text { Screen } \\
\text { recording } \\
\text { software }\end{array}$ & \multicolumn{1}{|c|}{ Aim of use of the software } \\
\hline $\begin{array}{l}\text { Conceptualizing and } \\
\text { assessing translational } \\
\text { creativity: teaching } \\
\text { and professional } \\
\text { implications (2015- } \\
\text { 2017) }\end{array}$ & $\begin{array}{l}\text { Translation, Teaching } \\
\text { and Cognition, } \\
\text { Universidad de Murcia } \\
\text { (TREC 2015d) }\end{array}$ & Camstudio & $\begin{array}{l}\text { To assess the impact of } \\
\text { creativity on the translation } \\
\text { process when working with } \\
\text { different types of texts. }\end{array}$ \\
\hline $\begin{array}{l}\text { MovEs II: Translation } \\
\text { and Creativity (2014- } \\
\text { 2016) }\end{array}$ & $\begin{array}{l}\text { Translation, Teaching } \\
\text { and Cognition, } \\
\text { Universidad de Murcia } \\
\text { (TREC, 2015c) }\end{array}$ & Camstudio & $\begin{array}{l}\text { To assess the impact of creativity } \\
\text { on the translation process of } \\
\text { students and professionals. }\end{array}$ \\
\hline Cognitive and & Maureen Ehrensberger- & Camtasia & To capture the translation and \\
\hline
\end{tabular}


This is a post-print version of the following paper published online $24^{\text {th }}$ of February, 2017:

KUZNIK, Anna; VERD, Joan Miquel; OLALLA-SOLER, Christian (2016) "Mixed methods, mixed tools. The use of computer software for integrated qualitative and quantitative analysis", Journal of Research Design and Statistics in Linguistics and Communication Science [JRDS], 3.1. (December 2016), pp. 76-109, DOI: 10.1558/irds.32360 , URI: https://journals.equinoxpub.com/index.php/JRDS/article/view/32360 , special issue "Mixed Methods" guest-edited by Anna Kuznik and Joan Miquel Verd, ISSN: 2052-417X (Print), 20524188 (Online)

\begin{tabular}{|c|c|c|c|}
\hline $\begin{array}{l}\text { Physical Ergonomics } \\
\text { of Translation (2013- } \\
2015)\end{array}$ & $\begin{array}{l}\text { Dow, Andrea Hunziker } \\
\text { Heeb, Gary Massey } \\
\text { (project team), Zurich } \\
\text { University of Applied } \\
\text { Sciences (Ehrensberger- } \\
\text { Dow and Massey, 2014) }\end{array}$ & & $\begin{array}{l}\text { revision processes of participants } \\
\text { and their interaction with the } \\
\text { computer. }\end{array}$ \\
\hline $\begin{array}{l}\text { Instrumental } \\
\text { subcompetence and } \\
\text { the translation of } \\
\text { subjectivity markers: } \\
\text { a casual or a causal } \\
\text { relationship? (2012- } \\
\text { 2014) }\end{array}$ & $\begin{array}{l}\text { María del Mar Gatti, } \\
\text { Mónica Giozza, Graciela } \\
\text { Caballero, Universidad } \\
\text { del Aconcagua (Giozza, } \\
\text { 2013) }\end{array}$ & Camtasia & $\begin{array}{l}\text { To observe the translation process } \\
\text { of a group of translation students, } \\
\text { to record their searches on } \\
\text { documentation resources and to } \\
\text { assess their degree of cognitive } \\
\text { implication. }\end{array}$ \\
\hline $\begin{array}{l}\text { An empirical study of } \\
\text { translation } \\
\text { competence } \\
\text { acquisition in written } \\
\text { translation (2010- } \\
\text { 2012) }\end{array}$ & $\begin{array}{l}\text { PACTE Group, } \\
\text { Universitat Autònoma de } \\
\text { Barcelona (PACTE, } \\
\text { 2014) }\end{array}$ & Camtasia & $\begin{array}{l}\text { To observe the participants' } \\
\text { translation process, to capture the } \\
\text { time spent translating, to record } \\
\text { the participants' actions and their } \\
\text { consultations on documentation } \\
\text { resources. }\end{array}$ \\
\hline $\begin{array}{l}\text { Capturing Translation } \\
\text { Processes (2009- } \\
\text { 2012) }\end{array}$ & $\begin{array}{l}\text { Maureen Ehrensberger- } \\
\text { Dow, Andrea Hunziker } \\
\text { Heeb, Gary Massey } \\
\text { (project team), Zurich } \\
\text { University of Applied } \\
\text { Sciences (Ehrensberger- } \\
\text { Dow and Massey, 2008) }\end{array}$ & Camtasia & $\begin{array}{l}\text { To trace the development of the } \\
\text { translated text, the revisions to the } \\
\text { text, search terms and electronic } \\
\text { resources, and to record the } \\
\text { translators' verbal comments on } \\
\text { the translation process while they } \\
\text { watch their recording. }\end{array}$ \\
\hline $\begin{array}{l}\text { An empirical study of } \\
\text { translation } \\
\text { competence (2001- } \\
\text { 2005) }\end{array}$ & $\begin{array}{l}\text { PACTE Group, } \\
\text { Universitat Autònoma de } \\
\text { Barcelona (PACTE, } \\
\text { 2008) }\end{array}$ & $\begin{array}{l}\text { Proxy and } \\
\text { Camtasia }\end{array}$ & $\begin{array}{l}\text { To observe the participants' } \\
\text { translation process, to capture the } \\
\text { time spent translating and to } \\
\text { record the participants' actions. }\end{array}$ \\
\hline $\begin{array}{l}\text { Learning processes } \\
\text { and assessment in } \\
\text { acquisition of } \\
\text { translation } \\
\text { competence (1997- } \\
\text { 2000) }\end{array}$ & $\begin{array}{l}\text { PACTE Group, } \\
\text { Universitat Autònoma de } \\
\text { Barcelona (PACTE, } \\
\text { 2001) }\end{array}$ & Proxy & $\begin{array}{l}\text { To observe the participants' } \\
\text { translation process, to record } \\
\text { participants' modifications of their } \\
\text { translation, to capture the time } \\
\text { spent translating and to record } \\
\text { their searches in documentation }\end{array}$ \\
\hline
\end{tabular}


KUZNIK, Anna; VERD, Joan Miquel; OLALLA-SOLER, Christian (2016) "Mixed methods, mixed tools. The use of computer software for integrated qualitative and quantitative analysis", Journal of Research Design and Statistics in Linguistics and Communication Science [JRDS], 3.1. (December 2016), pp. 76-109, DOI: 10.1558/irds.32360 , URI: https://journals.equinoxpub.com/index.php/JRDS/article/view/32360 , special issue "Mixed Methods" guest-edited by Anna Kuznik and Joan Miquel Verd, ISSN: 2052-417X (Print), 20524188 (Online)

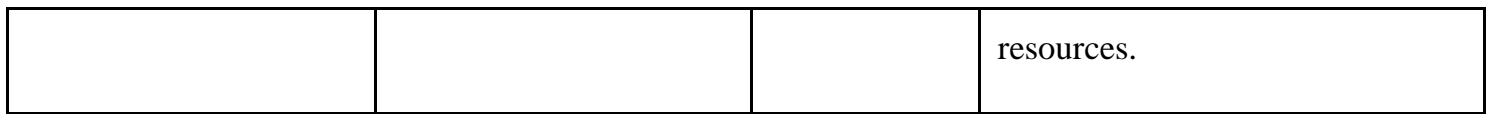

[page 85 in published version:]

The TREC website features 32 publications related to research studies in which screen activity recording software was used. From the studies in Table 1, we selected the two that we know best and present them below as examples of how Camtasia is used.

[page 86 in published version:]

\subsubsection{The use of Camtasia in PACTE's Translation Competence and Translation Competence Acquisition experiments}

Since its foundation in 1997, PACTE has been carrying out experimental research into translation competence and its acquisition. PACTE's research is divided into four stages: translation competence, acquisition of translation competence, establishment of competence levels and competence assessment. The group is currently conducting research related to the establishment of competence levels.

For the first two stages, PACTE conducted experimental research. The first experiment (on Translation Competence, TC) was conducted in 2005-2006 and aimed to validate PACTE's translation competence model (PACTE, 2003; Hurtado Albir, in press). The second (on Translation Competence Acquisition, TCA) was conducted in 2011 and aimed to analyze how translation competence is acquired in translator training (PACTE 2014; 2015; Kuznik and Olalla-Soler, in press).

Before the first experiment, PACTE conducted an exploratory test in 2000 (PACTE 2002a; 2002b) and a pilot test in 2004 (PACTE 2005a; 2005b). In both tests, Proxy, a remote monitoring program, had been used to observe and record the participants' translation process. However, the fifth version of this software did not allow the participants' translation process to be recorded, so Camtasia was introduced. Camtasia was used to record the participants' activity on the computer (and to see the recording afterwards) and Proxy 5.0 was used for remote control (PACTE, in press b). Researchers were able to detect through Proxy that participants were carrying out computer-external actions that could not be recorded by Camtasia. When this occurred, researchers noted the action taken on an observation chart.

Using Camtasia, the translation process of the participants was recorded from the start of the orientation stage to the end of the revision stage. Camtasia collected data for three of the six variables measured in both the TC and the TCA experiments. These 
KUZNIK, Anna; VERD, Joan Miquel; OLALLA-SOLER, Christian (2016) "Mixed methods, mixed tools. The use of computer software for integrated qualitative and quantitative analysis", Journal of Research Design and Statistics in Linguistics and Communication Science [JRDS], 3.1. (December 2016), pp. 76-109, DOI: 10.1558/irds.32360 , URI: https://journals.equinoxpub.com/index.php/JRDS/article/view/32360 , special issue "Mixed Methods" guest-edited by Anna Kuznik and Joan Miquel Verd, ISSN: 2052-417X (Print), 20524188 (Online)

three variables are Decision-Making, Efficacy of the Translation Process and Use of Instrumental Resources.

The aim of the variable Decision-Making was to collect data on the actions taken by the participants prior to adopting a definitive solution for the source text segments that were analyzed. Three categories of actions were defined: consultations of bilingual resources, consultations of alternative resources, and no consultations. Camtasia recordings were viewed and the action (or actions) taken for each participant and for each segment were recorded. The use of these actions or their combinations led to four sequences of actions. Frequencies were calculated for each sequence and for each experimental group (PACTE, in press c). Table 2 contains the template used for entering the recorded data from Camtasia.

[page 87 in published version:]

Table 2. Template for entering the recorded data from Camtasia for the variable Decision-Making (PACTE in press e) [page 87 in published version]

Subject:

Date of test:

Template completion date:
Text: Email virus strikes in new form

Target language:

Researcher/s:

Rich Point:Email virus strikes in new form

ACTION

$\begin{array}{lll}\text { START } & \text { END } & \text { STAGE } \\ \text { TIME } & \text { TIME } & \end{array}$

Bilingual dictionaries used:

\begin{tabular}{|l|l|l|}
\hline DICTIONARY & PRINTED /CD & SOLUTION COPIED? \\
\hline Collins & Printed CD & Yes No \\
\hline Larousse & Printed CD No \\
\hline Pons & Printed CD & Yes No \\
\hline EnciclopediaCatalana & Printed CD & Yes No \\
\hline Slaby & Printed CD & Yes No \\
\hline
\end{tabular}


KUZNIK, Anna; VERD, Joan Miquel; OLALLA-SOLER, Christian (2016) "Mixed methods, mixed tools. The use of computer software for integrated qualitative and quantitative analysis", Journal of Research Design and Statistics in Linguistics and Communication Science [JRDS], 3.1. (December 2016), pp. 76-109, DOI: 10.1558/irds.32360 , URI: https://journals.equinoxpub.com/index.php/JRDS/article/view/32360 , special issue "Mixed Methods" guest-edited by Anna Kuznik and Joan Miquel Verd, ISSN: 2052-417X (Print), 20524188 (Online)

\begin{tabular}{|l|l|l|}
\hline Online: & \multicolumn{1}{|l|}{ Yes No } \\
\hline \multirow{3}{*}{ Solution: } & & Acceptable \\
\cline { 2 - 3 } & & Semi-Acceptable \\
\cline { 2 - 3 } & & Non-Acceptable \\
\hline
\end{tabular}

The aim of the variable Efficacy of the Translation Process was to measure the time that participants spend on the translation task from the beginning of the orientation stage to the end of the revision stage. Data was collected from the Camtasia recordings. Since the whole screen was recorded, the time reference was the clock that Windows shows on the taskbar (PACTE, in press d).

[page 88 in published version:]

The hour and minute of the beginning and end of each stage (orientation, development and revision) was entered on a spreadsheet, followed by the time of each stage and of the whole translation task. Since all participants started the translation at the same time when the researchers in charge of the direct observation gave permission to do so, the start time of the orientation phase was entered on the direct observation charts.

The objective of the variable Use of Instrumental Resources was to collect data on the use of resources in electronic format during the translation task. The data collected was limited to the use of electronic resources after direct observation had revealed that translators consulted few printed resources. The data included the stage at which a search was carried out, the time at which the search started and ended, the segment of the source text that led to the search, the resource used, and the type of search carried out. (Kuznik, in press; Kuznik and Olalla-Soler, in press). The types of resources and the types of searches were categorized after all recordings had been viewed. Figure 3.4. shows a screenshot of the spreadsheet used to enter this data in the TCA experiment (Kuznik and Olalla-Soler, in press). 
KUZNIK, Anna; VERD, Joan Miquel; OLALLA-SOLER, Christian (2016) "Mixed methods, mixed tools. The use of computer software for integrated qualitative and quantitative analysis", Journal of Research Design and Statistics in Linguistics and Communication Science [JRDS], 3.1. (December 2016), pp. 76-109, DOI: 10.1558/irds.32360 , URI: https://journals.equinoxpub.com/index.php/JRDS/article/view/32360 , special issue "Mixed Methods" guest-edited by Anna Kuznik and Joan Miquel Verd, ISSN: 2052-417X (Print), 20524188 (Online)

\begin{tabular}{|c|c|c|c|c|c|c|c|c|}
\hline Curso & Lengua & $\begin{array}{c}\text { Punto } \\
\text { Rico }\end{array}$ & $\begin{array}{l}\text { Fase de } \\
\text { consulta }\end{array}$ & $\begin{array}{l}\text { Hora de } \\
\text { inicio }\end{array}$ & $\begin{array}{l}\text { Hora de } \\
\text { final }\end{array}$ & $\begin{array}{l}\text { Nombre del } \\
\text { recurso }\end{array}$ & $\begin{array}{l}\text { Tipo de } \\
\text { recurso }\end{array}$ & $\begin{array}{l}\text { Tipo de } \\
\text { consulta }\end{array}$ \\
\hline 20 & Alemán & PR1 & Desarrollo & $15: 53$ & $12: 53$ & PONS.DE & Diccionario bilinguie & Equivalencia \\
\hline 20 & Alemán & PR1 & Desarrollo & $15: 53$ & $12: 53$ & G00GLE & Buscador general & Palabra clave \\
\hline 20 & Alemán & PR2 & Desarrollo & $16: 30$ & $16: 30$ & PONS.DE & Diccionario bilinguie & Equivalencia \\
\hline 20 & Alemán & PR3 & Desarrollo & $15: 59$ & $15: 59$ & PONS.DE & Diccionario bilinguie & Equivalencia \\
\hline 20 & Alemán & PR3 & Desarrollo & 16:01 & 16:01 & PONS.DE & Buscador general & Contexto \\
\hline 20 & Alemán & PR4 & Desarrollo & $16: 30$ & $16: 30$ & PONS.DE & Diccionario bilinguie & Equivalencia \\
\hline 20 & Alemán & PR4 & Desarrollo & $16: 33$ & 16:33 & GOOGLE & Buscador general & Palabra clave \\
\hline 20 & Alemán & PR4 & Desarrollo & $16: 33$ & $16: 33$ & WIKIPED|A & \begin{tabular}{|l} 
Diccionario bilinguie \\
\end{tabular} & Equivalencia \\
\hline 20 & Alemán & PR4 & Desarrollo & $16: 34$ & $16: 34$ & WIKIPEDIA & Enciclopedia & Interna \\
\hline 20 & Alemán & PR4 & Desarrollo & $16: 35$ & $16: 35$ & GO0GLE & Buscador general & Palabra clave \\
\hline 20 & Alemán & PR4 & Desarrollo & $16: 35$ & $16: 35$ & WIKIPED|A & Buscador general & Definición \\
\hline 20 & Alemán & PR4 & Desarrollo & $16: 35$ & $16: 37$ & GOOGLE & Buscador general & Contexto \\
\hline 20 & Alemán & PR1 & Desarrollo & $15: 50$ & 15:51 & PONS.DE & Buscador general & Equivalencia \\
\hline 20 & Alemán & PR1 & Desarrollo & $15: 51$ & $15: 52$ & GOOGLE & Buscador general & Pref. Linguística \\
\hline 20 & Alemán & PR1 & Desarrollo & $15: 52$ & 15:52 & WIKIPEDIA & Enciclopedia & Definición \\
\hline 20 & Alemán & PR2 & Desarrollo & $16: 52$ & $16: 53$ & PONS.DE & Diccionario bilingije & Equivalencia \\
\hline 20 & Alemán & PR3 & Desarrollo & $16: 09$ & $16: 10$ & PONS.DE & \begin{tabular}{|l} 
Diccionario bilinguie \\
\end{tabular} & Equivalencia \\
\hline 20 & Alemán & PR3 & Desarrollo & $16: 10$ & $16: 11$ & G00GLE TRANS & Diccionario bilinguie & Equivalencia \\
\hline 20 & Alemán & PR3 & Desarrollo & $16: 13$ & $16: 13$ & PONS.DE & Diccionario bilingije & Equivalencia \\
\hline 20 & Alemán & PR3 & \begin{tabular}{|l|} 
Desarrollo \\
\end{tabular} & $16: 13$ & $16: 13$ & G00GLE & \begin{tabular}{|l|} 
Buscador general \\
\end{tabular} & Palabra clave \\
\hline 20 & Alemán & PR3 & Desarrollo & $16: 13$ & $16: 13$ & WIKIPEDIA & Enciclopedia & Definición \\
\hline 20 & Alemán & PR3 & Desarrollo & $16: 23$ & $16: 24$ & PONS.DE & Diccionario bilingije & Equivalencia \\
\hline 20 & Alemán & PR4 & Desarrollo & $16: 52$ & $16: 53$ & PONS.DE & Diccionario bilinguie & Equivalencia \\
\hline 20 & Alemán & PR4 & Desarrollo & $16: 54$ & $16: 54$ & G00GLE & Buscador general & Contexto \\
\hline 20 & Alemán & PR4 & Desarrollo & $16: 54$ & 16:55 & PONS.DE & Diccionario bilinguie & Equivalencia \\
\hline 20 & Alemán & PR1 & Desarrollo & $15: 51$ & $15: 52$ & PONS.DE & Diccionario bilinguie & Equivalencia \\
\hline 20 & Alemán & PR3 & Desarrollo & $16: 03$ & $16: 03$ & PONS.DE & Diccionario bilinguie & Equivalencia \\
\hline 20 & Alemán & PR3 & Desarrollo & 16:08 & 16:08 & PONS.DE & Diccionario bilinguie & Equivalencia \\
\hline
\end{tabular}

Figure 3.4. Screenshot of the spreadsheet used to enter the recorded data from Camtasia for the variable Use of Instrumental Resources [page 88 in published version]

For the three variables the same procedure was followed: first, the participants' translation process was recorded; second, the recordings were viewed, and if a template for entering the required data already existed, it was filled in for each participant. If the template was not yet available, it had to be designed,

[page 89 in published version:]

trialled and then used to enter the data. Finally, statistical analysis was performed with the statistical packages $S A S$ and Deducer.

\subsection{Exploring methodological and technical limits}

When using on-screen recording software such as Camtasia, researchers undoubtedly depend on the computer running smoothly. Computer system errors may cause a loss of data if the recording is lost. This was the case of PACTE's experiment on translation competence (PACTE, in press c), in which three recordings were lost because Camtasia was disconnected. Fortunately, the sample size was big enough and this loss did not affect the study greatly.

Camtasia is able to record keystroke input but only for shortcuts. Also, this is 
KUZNIK, Anna; VERD, Joan Miquel; OLALLA-SOLER, Christian (2016) "Mixed methods, mixed tools. The use of computer software for integrated qualitative and quantitative analysis", Journal of Research Design and Statistics in Linguistics and Communication Science [JRDS], 3.1. (December 2016), pp. 76-109, DOI: 10.1558/irds.32360 , URI: https://journals.equinoxpub.com/index.php/JRDS/article/view/32360 , special issue "Mixed Methods" guest-edited by Anna Kuznik and Joan Miquel Verd, ISSN: 2052-417X (Print), 20524188 (Online)

only possible when the output file is coded in CAMREC. The shortcuts are shown in Camtasia Studio editor while the recording is played (Figure 3.5.). Camtasia does not replace keylogging programs such as Translog, so this limitation may increase the difficulty of collecting data. It is also not possible to use eye trackers with Camtasia, since video recording is limited to webcams. However, TechSmith has developed Morae, ${ }^{\mathrm{v}} \mathrm{a}$ remote monitoring program which does allow the use of eye trackers during viewing or recording of on-screen activity.

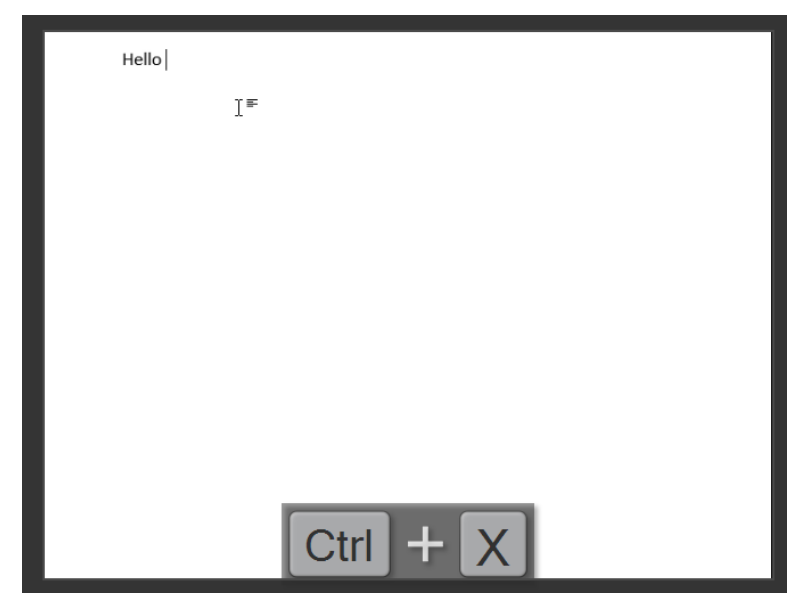

Figure 3.5. Preview of shortcuts in Camtasia Studio editor [page 89 in published version]

Though Camtasia can record visual and audio data, it may not be sufficient to collect all desired data. Although this program does not greatly affect the computer's performance, using many resource-intensive programs may slow down the computer's processes and affect ecological validity.

Halfway between the methodological and the technological limit, we must highlight the need for triangulation of data. Camtasia is a very interesting

[page 90 in published version:]

program for observing and analyzing the process followed by participants to complete a task and for identifying problem-solving strategies. However, actions taken by participants may be only a small part of the participants' problem-solving processes: one sees every action they perform, but not everything they think. It is therefore important to triangulate the data obtained on this level with data gathered with other instruments, such as eye-tracking, retrospective interviews or even instruments that 
KUZNIK, Anna; VERD, Joan Miquel; OLALLA-SOLER, Christian (2016) "Mixed methods, mixed tools. The use of computer software for integrated qualitative and quantitative analysis", Journal of Research Design and Statistics in Linguistics and Communication Science [JRDS], 3.1. (December 2016), pp. 76-109, DOI: 10.1558/irds.32360 , URI: https://journals.equinoxpub.com/index.php/JRDS/article/view/32360 , special issue "Mixed Methods" guest-edited by Anna Kuznik and Joan Miquel Verd, ISSN: 2052-417X (Print), 20524188 (Online)

monitor physiological reactions.

As a methodological limit, we would like to emphasize that this program may raise or lower ecological validity depending on how it is used. On the one hand, if a participant is performing a task and he/she is not aware that on-screen activity is being recorded, ecological validity may rise because he/she will not feel conditioned. However, the participant might discover that the program is being used and this would raise critical ethical problems for the research. On the other hand, if the participant is aware that his/her on-screen actions are being recorded, it is very likely that he/she will feel conditioned and avoid the use of certain strategies. Researchers need to make decisions on the use of this kind of software so as to balance ecological validity and their commitment to ethical research. In PACTE's TC and TCA experiments, participants were not told that Camtasia was running while they performed the experimental tasks. This decision was taken to ensure the ecological validity of the experiment and to avoid conditioning the participants' behaviour (PACTE, in press a). After completing the experimental tasks, they were informed that data from their translation product and process had been gathered, and they were explicitly told that their translation process had been recorded using Camtasia. If they agreed to collaborate in the experiment, they had to sign a document stating that the "participants agreed to allow PACTE to use the data collected from the experiment, and PACTE guaranteed data confidentiality and that the data would only be used for research purposes" (PACTE, in press b).

\subsection{Potential for integration of qualitative and quantitative analysis}

Although raw data recorded from Camtasia is usually categorical, in some cases quantitative data such as time measures can easily be extracted from on-screen activity recordings. The examples presented in section 3.2.1 illustrate how Camtasia is suitable for combining quantitative and qualitative analysis:

- The conversion of categorical data into quantitative data such as the actions performed by participants prior to adopting a translation solution serves as an example of quantitative translation, since these actions were analyzed using frequency tables. In these frequency tables the mode was used as a descriptive statistic of central tendency, and statistical tests for categorical variables were carried out.

[page 91 in published version:]

- Quantitative continuous data was collected when the time spent on the translation task was recorded. Descriptive statistics such as the mean, the median 
KUZNIK, Anna; VERD, Joan Miquel; OLALLA-SOLER, Christian (2016) "Mixed methods, mixed tools. The use of computer software for integrated qualitative and quantitative analysis", Journal of Research Design and Statistics in Linguistics and Communication Science [JRDS], 3.1. (December 2016), pp. 76-109, DOI: 10.1558/irds.32360 , URI: https://journals.equinoxpub.com/index.php/JRDS/article/view/32360 , special issue "Mixed Methods" guest-edited by Anna Kuznik and Joan Miquel Verd, ISSN: 2052-417X (Print), 20524188 (Online)

and the standard deviation were computed, and inferential tests were used after checking the distribution of the variable.

- Quantitative ordinal data was gathered in the variable Use of Instrumental Resources: this data included the number of searches performed by each participant and even the number of different types of searches or resources used.

In almost every case, the analysis of data gathered from Camtasia starts with a qualitative stage in which categories are created to interpret the qualitative data collected. After categorization, the analysis starts a quantitative stage in which researchers decide the best scale for measuring the categorized data: is a categorical scale (what types of searches do participants perform, e.g., searches for equivalents, for definitions, for synonyms, etc.) the most suitable one or is a numerical scale (how many types of searches do participants perform, e.g., only a single type of search, a combination of two, three, four types of search, etc.) more appropriate?

Last but not least, we need to stress again the need for triangulating methods. Camtasia and other on-screen recording programs provide important data on problemsolving strategies when a given task is completed, but the actions taken by the participants might be a small part of what they have thought. It is therefore essential to combine on-screen recording software with other tools that are able to gather a deeper level of cognitive implication.

\section{EdEt - Editor for Ethnographers}

\subsection{General features and functions}

EdEt Editor for Ethnographers (EdEtEdytorEtnograficzny) is an easy-to-use, free CAQDAS program. It was created in 2005 in Poland for students of the Institute of Ethnology and Cultural Anthropology of Warsaw University (InstytutEtnologiiiAntropologiiKulturowej - UniwersytetWarszawski, IEiAK UW) and for other students of the same university, with financial support from the Didactic Innovation Fund (FunduszInnowacjiDydaktycznych $U W$ ). When authorized by the IEiAK, EdEt may be used by other institutions. Copyrights belong to IwonaKaliszewska (2005-2011), the Institute of Ethnology and Cultural Anthropology UW and the Faculty of Mathematics, Informatics and Mechanics UW (WydziałMatematyki, InformatykiiMechaniki).

The program can be downloaded and explored from the following website:www.etnologia.uw.edu.pl/program-edet (last accessed on 19-07-2016). Three 
This is a post-print version of the following paper published online $24^{\text {th }}$ of February, 2017:

KUZNIK, Anna; VERD, Joan Miquel; OLALLA-SOLER, Christian (2016) "Mixed methods, mixed tools. The use of computer software for integrated qualitative and quantitative analysis", Journal of Research Design and Statistics in Linguistics and Communication Science [JRDS], 3.1. (December 2016), pp. 76-109, DOI: 10.1558/irds.32360 , URI: https://journals.equinoxpub.com/index.php/JRDS/article/view/32360 , special issue "Mixed Methods" guest-edited by Anna Kuznik and Joan Miquel Verd, ISSN: 2052-417X (Print), 20524188 (Online)

language versions are available: Polish, English and Spanish. The main view of

[page 92 in published version:]

a new, empty EdEt project in the English version (v. 2.1.99.1) is presented in Figure 4.1 (a screenshot of the first step in the creation of a new project).

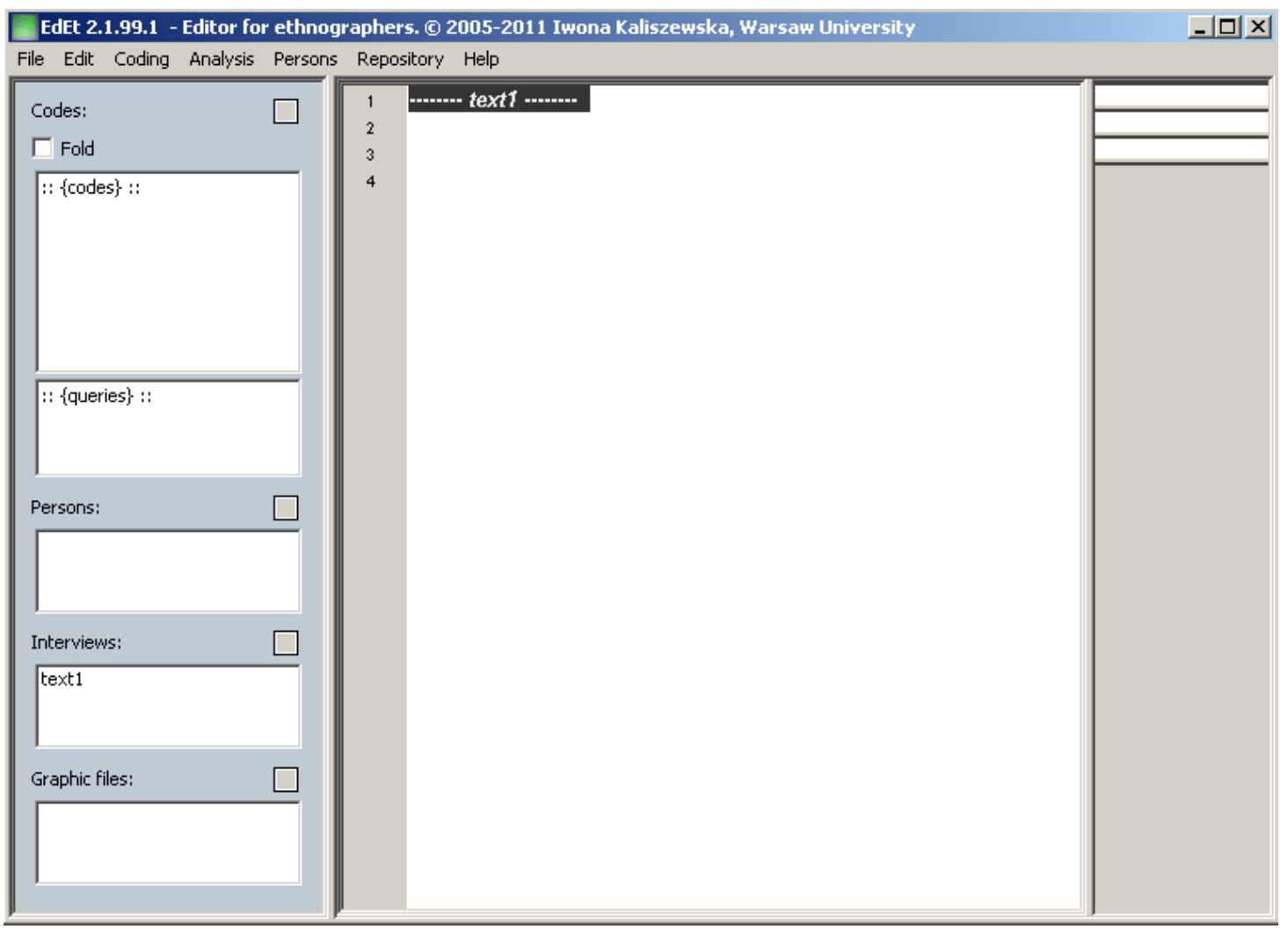

Figure 4.1. Main view of a new EdEt project in English version (v. 2.1.99.1) [page 92 in published version]

EdEtwas initially designed as a didactic tool for supporting the work of undergraduate students with ethnographical material (field work notes and transcribed interviews with several participants), but it is also suitable for other qualitative material. $E d E t$ aids work on ethnographical interviews, focus group sessions, field notes, book fragments and other texts worked on by social scientists on an everyday basis (Kaliszewska 2008, 2009). Initially, it supported only texts, but later versions allowed work on graphic files (photos of slogans used during political campaigns, maps of 
KUZNIK, Anna; VERD, Joan Miquel; OLALLA-SOLER, Christian (2016) "Mixed methods, mixed tools. The use of computer software for integrated qualitative and quantitative analysis", Journal of Research Design and Statistics in Linguistics and Communication Science [JRDS], 3.1. (December 2016), pp. 76-109, DOI: 10.1558/irds.32360 , URI: https://journals.equinoxpub.com/index.php/JRDS/article/view/32360 , special issue "Mixed Methods" guest-edited by Anna Kuznik and Joan Miquel Verd, ISSN: 2052-417X (Print), 20524188 (Online)

villages and housing estates sketched by informants, and photos of advertisements; Kaliszewska 2009:200).

When designing EdEt, the IEiAK UW was aware that they needed a tool that could be used on field computers, was easy to use, supported interview analysis, enabled easy search and collaborative work on field material, facilitated archiving, and allowed supervision of students during their first period of research (Kaliszewska 2009:199). The initial program requirements were coding and building code hierarchy, a repository accessible by different users, a centralized internet archive, adaptation for work on interviews and an easy interface. It also had to be lightweight and free.

[page 93 in published version:]

The main functions are the same as those of other CAQDAS applications (Bieliński, Iwińska and Rosińska-Kordasiewicz, 2007): integrating all pieces of data gathered (texts and graphic files), coding, building code hierarchy and editing the results obtained. It thus helps to organize all types of textual and graphic material in the same study, to analyzeit and to share it with other researchers who are working on the same study (supervisors or other students).

However, EdEt has a special interview facility that makes analysis of interviews with several participants (transcribed or collected from online conversations and chats on fora or Facebook; Kaliszewska, 2009:200) easier, faster and more accurate. This feature is a semi-automatic division of statements among interlocutors, adding characteristics of people and interviews. The researcher thus maintains his/her empirical data contextualized properly during the whole data analysis process.

This advanced system of establishing characteristics of people and interviews is very useful when contextualized queries on the material are run. The program can be used to select a specific statement from a particular individual. The researcher can ask the program to give him/her a chosen statement of participants, with chosen features (age, sex, education, attitudes and other individual traits), on chosen topics, and from chosen interviews (Kaliszewska, 2009:199). As Kaliszewska states (2009:199), this $E d E t$ feature can be especially useful for discourse analysis.

The initial tests of EdEt reported by Kaliszewska (2008; 2009:201--202) were carried out on material collected in an ethnographic field study in Dagestan (Caucasia; 2004--2007). The textual material embraced biographical interviews, everyday narratives and participant observation notes. In Kaliszewska's study no a priori research issue had been chosen: the researcher just wanted to see what emerged from the data collected, and only then to make decisions on the research topic and categories used in 
KUZNIK, Anna; VERD, Joan Miquel; OLALLA-SOLER, Christian (2016) "Mixed methods, mixed tools. The use of computer software for integrated qualitative and quantitative analysis", Journal of Research Design and Statistics in Linguistics and Communication Science [JRDS], 3.1. (December 2016), pp. 76-109, DOI: 10.1558/irds.32360 , URI: https://journals.equinoxpub.com/index.php/JRDS/article/view/32360 , special issue "Mixed Methods" guest-edited by Anna Kuznik and Joan Miquel Verd, ISSN: 2052-417X (Print), 20524188 (Online)

the analysis.

$E d E t$ does not do the analysis for the researcher but it clearly helps to organize, homogenize, edit and analyze all the material gathered from a qualitative point of view. Following a mainly inductive strategy, by seeing what emerges from the material one can add contextualized information, choose a research topic, change topic if required, think of further questions and deepen the study later. Moreover, a deductive strategy is also possible (Kaliszewska, 2009:202--203) when categories for the analysis are established a priori.

\subsection{Examples of application of EdEt in empirical studies}

As the available literature shows, the EdEtsoftware is not very well-known, nor is it frequently used by senior researchers in more advanced studies. In this section, two groups of studies are presented.

[page 94 in published version:]

\subsubsection{Examples of qualitative uses}

Recently, EdEt was used by García-Álvarez, López-Sintas and Samper-Martínez (2015) in the field of cultural studies, digital leisure and consumer behavior. The authors addressed the subjective experience of social network gamers playing Restaurant City, a game hosted on Facebook. They adopted a netnographic approach to studying the culture of transient internet communities shaping the off-line player communities. The authors state that the data was analyzed using a qualitative thematic approach and EdEtbut they give no details of the analysis. ${ }^{\mathrm{vi}}$

In the study reported by López-Sintas, Rojas de Francisco and García-Álvarez (2015), the narratives of 30 individualswere explored in an endeavor to identify the properties of digital leisure and paid-work activities performed inside and outside their usual contexts. The qualitative analysis was assisted by EdEt, an editor for ethnographers and Cassandre's environment for qualitative analysis (López-Sintas et al., 2015:87). The authors comment on their work of coding the data collected and their methodological procedure:

We inductively constructed a simple set of themes in order to group narratives according to the activities performed, the technologies used for the activities, the spaces (work and leisure) where the activities were performed, the times when the activities were performed (work and leisure), and one final theme that 
KUZNIK, Anna; VERD, Joan Miquel; OLALLA-SOLER, Christian (2016) "Mixed methods, mixed tools. The use of computer software for integrated qualitative and quantitative analysis", Journal of Research Design and Statistics in Linguistics and Communication Science [JRDS], 3.1. (December 2016), pp. 76-109, DOI: 10.1558/irds.32360 , URI: https://journals.equinoxpub.com/index.php/JRDS/article/view/32360 , special issue "Mixed Methods" guest-edited by Anna Kuznik and Joan Miquel Verd, ISSN: 2052-417X (Print), 20524188 (Online)

grouped the meanings assigned to activities. During this process, in order to improve the validity of the categories, we held several meetings of different durations to share and discuss our interpretations of texts, codes, categories, and properties [...]. After coding, simple and conditional searches of the cooccurrence of categories produced the meanings of the activities performed (and the technologies used) in different spaces and times. (López-Sintas et al., 2015:87)

A quantitative analysis was not integrated into the analysis carried out with EdEtin either of the studies (García-Álvarez et al., 2015, López-Sintas et al., 2015) because of the clearly and exclusively qualitative research goals.

Another of the fields of application of EdEt known to date is the field of foreign language acquisition and translation studies. Kuznik (2015) and Kuznik and Little (in press) present a study carried out with an inductive methodology, with the aim of identifying the conditions of occupational integration (economic activities and the employability axes) of French philology undergraduate students, including translators, after their studies at the Institute of Romance Studies (InstytutFilologiiRomańskiej) of Wrocław University (UniwersytetWrocławski) in Poland between 2011 and 2014.

The initial two pools of data reflect the students' point of view and are presented in Kuznik (2015) (see also Kuznik and Little in press). Two surveys were conducted (see also: Kuznik, Hurtado Albir and Espinal, 2010): the first one dealt with students' motivation for studying French language and civilization

[page 95 in published version:]

and for practicing the future jobs; the second one dealt with the first academic studies undertaken by the students. The first survey was analyzed using EdEt software (Kuznik, 2015:293). The data collected was analyzed and reduced to the main conceptual, ad hoc categories (Figure 4.2.), all presented in detail in Kuznik (2015:293-295). 
This is a post-print version of the following paper published online $24^{\text {th }}$ of February, 2017:

KUZNIK, Anna; VERD, Joan Miquel; OLALLA-SOLER, Christian (2016) "Mixed methods, mixed tools. The use of computer software for integrated qualitative and quantitative analysis", Journal of Research Design and Statistics in Linguistics and Communication Science [JRDS], 3.1. (December 2016), pp. 76-109, DOI: 10.1558/irds.32360 , URI: https://journals.equinoxpub.com/index.php/JRDS/article/view/32360 , special issue "Mixed Methods" guest-edited by Anna Kuznik and Joan Miquel Verd, ISSN: 2052-417X (Print), 20524188 (Online)

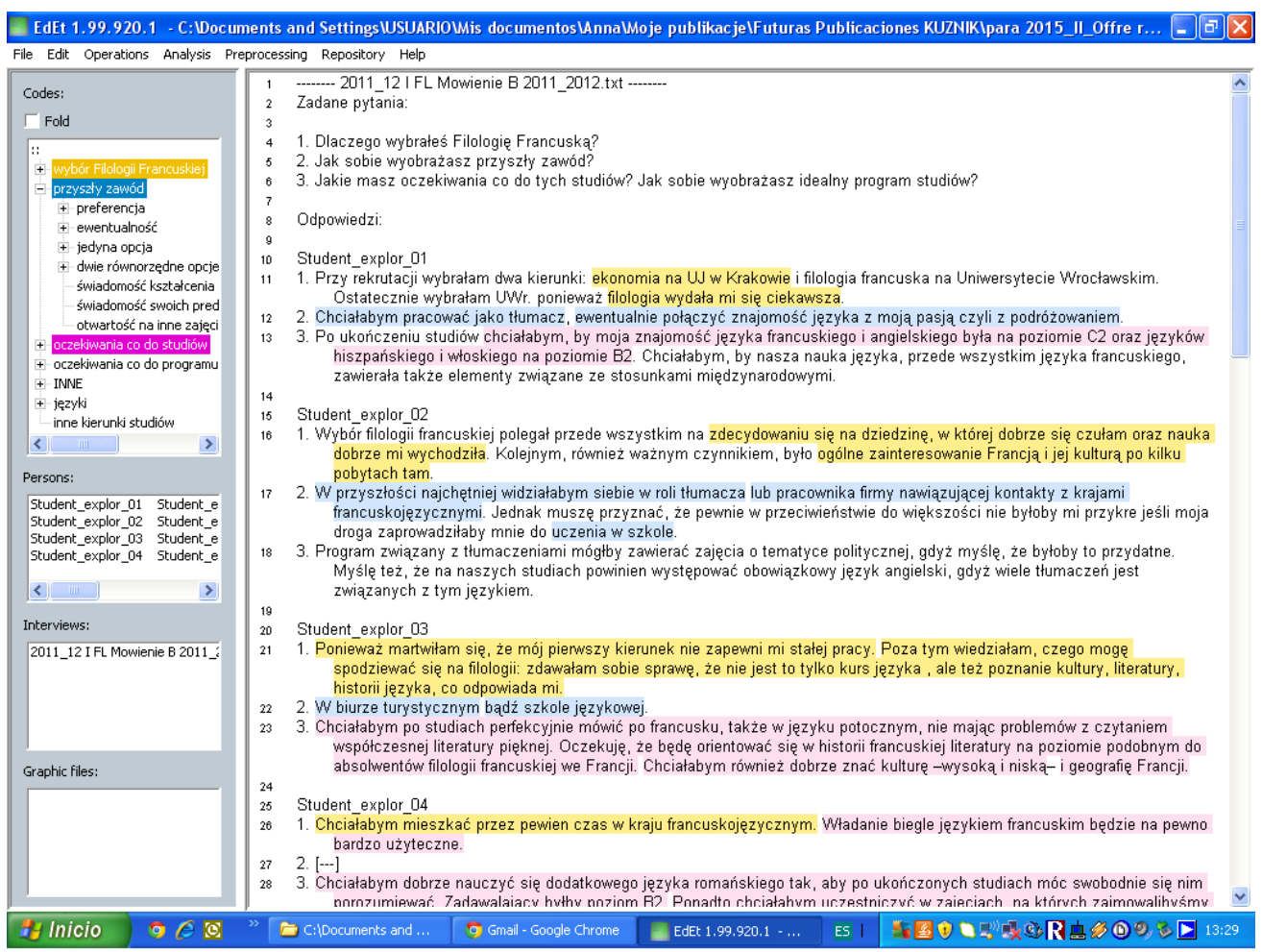

Figure 4.2. Analysis in EdEt of the students' motivation and future jobs among French philology students (Kuznik 2015; Kuznik and Little in press) [page 95 in published version]

Although the study on the conditions of occupational integration of French philology undergraduate students in Poland took a clearly qualitative, inductive approach, the four pools of data (two from the students' point of view and two from the employers' point of view) were reduced to different conceptual categories, so it was not necessary to use EdEt during the whole study. It was only used for the first student survey but proved very helpful. The data analyzed with EdEt was only textual (without graphic files) and no quantitative analyses were performed.

\subsubsection{Qualitative use and quantitizing strategy}

$E d E t$ 's third known field of application is translation studies and the sociology of work. Kuznik (2010) analyses and describes all the activities performed by in-house translators in their jobs. She poses the following research questions: 
KUZNIK, Anna; VERD, Joan Miquel; OLALLA-SOLER, Christian (2016) "Mixed methods, mixed tools. The use of computer software for integrated qualitative and quantitative analysis", Journal of Research Design and Statistics in Linguistics and Communication Science [JRDS], 3.1. (December 2016), pp. 76-109, DOI: 10.1558/irds.32360 , URI: https://journals.equinoxpub.com/index.php/JRDS/article/view/32360 , special issue "Mixed Methods" guest-edited by Anna Kuznik and Joan Miquel Verd, ISSN: 2052-417X (Print), 20524188 (Online)

[page 96 in published version:]

- What does working in the translation services sector today really mean?

- How is this work organized and what do people think about it?

- What activities are covered by the cost of each worker in the translation sector?

Following initial empirical research in Rennes (2007), the researcher collected data in Barcelona (2009) from 10 small and medium-sized enterprises offering translation services. She interviewed managers (7 interviews), spent 6 four-hour sessions observing in-house translators at work, and analyzed 26 reports by students who had completed placements in the companies.

After all the empirical material (transcribed interviews, direct observation notes in Word tables and placement reports) had been collected and stored in digital format, an electronic corpus was created. This corpus was in plain text (.txt) format so it could be processed using EdEt. Creating the corpus involved the following:

(1) Anonymizing data. Data indicative of the identity of the companies or individuals involved in the study (i.e. names of people, companies and customers, and types of jobs that might allow for identification) was removed or replaced by identifiers, replacing one datum with another (e.g. changing a participant's gender) or omitting personal data. Every informant was assigned an identifier and their characteristics and values were defined for subsequent entry in an EdEt project.

(2) Editing files in Word. Before the electronic files were converted to text format and copied into the new EdEtanalysis project, various steps were taken to adapt their formatting. Particular attention was paid to the position of the end-of-paragraph symbol, whichEdEt uses to divide text into (informants') statements. All bold formatting, italics, lists and unnecessary spaces were removed. The transcribed interviews were put into a standardized form of oral Spanish. The Spanish and Catalan language used was spellchecked, as EdEt lacks a built-in language correction function. Direct observation field notes were transcribed in direct observation charts in Word format (Figure 4.3).

In the Word files, activity duration (in the format hh:mm, e.g. [00:05]) was calculated for all the companies except YELLOW, indicating that data could not be collected in the same way as in other companies. The columns of all the tables in Word (with durations calculated) were then converted into text files. Field notes from the first session (observation in VIOLET) were added.

For placement reports, a file identifier system was created to distinguish between single-semester and year-long placements. The reports' content was then divided into three sections, namely placement activity description, 
This is a post-print version of the following paper published online $24^{\text {th }}$ of February, 2017:

KUZNIK, Anna; VERD, Joan Miquel; OLALLA-SOLER, Christian (2016) "Mixed methods, mixed tools. The use of computer software for integrated qualitative and quantitative analysis", Journal of Research Design and Statistics in Linguistics and Communication Science [JRDS], 3.1. (December 2016), pp. 76-109, DOI: 10.1558/irds.32360 , URI: https://journals.equinoxpub.com/index.php/JRDS/article/view/32360 , special issue "Mixed Methods" guest-edited by Anna Kuznik and Joan Miquel Verd, ISSN: 2052-417X (Print), 20524188 (Online)

[page 97 in published version:]

personal evaluation and comments. All content not envisaged in the placement report template (e.g. self-assessment) was included in the comments section.

\begin{tabular}{|c|c|c|c|c|c|c|c|}
\hline \multicolumn{8}{|c|}{ VIOLETA I; 20/01/2009; martes; 09:40-13:40 } \\
\hline \multicolumn{2}{|c|}{$\begin{array}{c}\text { Trad_1_VIOLETA } \\
\text { (mujer, joven, de } 25-30 \text { años; se comunica en } \\
\text { CA/ES; lleva gafas) }\end{array}$} & \multicolumn{2}{|c|}{$\begin{array}{c}\text { Trad_2 2-VIOLETA } \\
\text { (mujer, joven, de } 25-30 \text { años; se comunica } \\
\text { en CA; lleva gafas) }\end{array}$} & \multicolumn{2}{|c|}{\begin{tabular}{|c|} 
Trad_3_VIOLETA \\
(mujer,joven, de $25-30$ años; se comunica en \\
EN; lleva gafas)
\end{tabular}} & \multicolumn{2}{|c|}{ Incidencias en la sala } \\
\hline \multicolumn{8}{|c|}{ PRIMERA HORA DE OBSERVACION } \\
\hline 09:40 & .... Teclea, lee, reflexiona & $09: 40$ & ... Teclea, lee, reflexiona & & & & \\
\hline $09: 42$ & $\begin{array}{l}\text { Se pone cascos y llama por teléfono (CA): } \\
\text { no se pueden abrir los ficheros, llegan a un } \\
\text { acuerdo }[00: 05]\end{array}$ & $09: 45$ & Selevanta, sale [00:03] & $09: 45$ & $\begin{array}{l}\text { Llega, saca del bolso su comida (trae } \\
\text { la comida al trabajo), registra sumóvil } \\
\text { personal [00:04] }\end{array}$ & \multirow[t]{7}{*}{$09: 46$} & \multirow{7}{*}{$\begin{array}{l}\text { Entra otra } \\
\text { persona, saluda } \\
\text { y sale, llegan } \\
\text { trespersonasy } \\
\text { saludan-hora de } \\
\text { la llegada al } \\
\text { trabajo }\end{array}$} \\
\hline 09:47 & $\begin{array}{l}\text { Apunta algo en el cuademo enla derecha } \\
{[00: 03]}\end{array}$ & \multirow[t]{4}{*}{ 09:48 } & \multirow[t]{4}{*}{$\begin{array}{l}\text { Trae un té, se sienta, se pone a } \\
\text { trabajar, lee, bebe el té [00:14] }\end{array}$} & $09: 49$ & Revisa el correo electrónico $[00: 02]$ & & \\
\hline 09:50 & $\begin{array}{l}\text { Ja estáfet!!, comprueba qué está hecho y qué } \\
\text { no }[00: 05]\end{array}$ & & & $09: 51$ & Gestiona los ficheros, teclea [00:01] & & \\
\hline 09:55 & $\begin{array}{l}\text { Vuelve a llamar por teléfono -Skype, pide } \\
\text { aclaraciones al cliente que envio un texto, } \\
\text { acuerdan detalles sobre el texto recibido: } \\
\text { será en } 3 \text { idiomas [00:05] }\end{array}$ & & & $09: 52$ & $\begin{array}{l}\text { Se levanta, sale a otra sala, deja } \\
\text { abierta la pantalla con el gestor de } \\
\text { correo [00:08] }\end{array}$ & & \\
\hline 10:00 & $\begin{array}{l}\text { Sale para comprobar algo, vuelve enseguida, } \\
\text { crecela tensión }[00: 02]\end{array}$ & & & $10: 00$ & Vuelve, contesta los mails [00:02] & & \\
\hline $10: 02$ & $\begin{array}{l}\text { Llega un colega (lo ha llamado), comentan } \\
\text { un problema informático No permiteextraer } \\
\text { textos, intentan solucionarlo [00:03] }\end{array}$ & \multirow[t]{2}{*}{$10: 02$} & \multirow[t]{2}{*}{$\begin{array}{l}\text { Come el bocata delante de la } \\
\text { pantalla [00:05] }\end{array}$} & \multirow[t]{2}{*}{ 10:02 } & \multirow{2}{*}{$\begin{array}{l}\text { Sale y vuelva enseguida con agua, } \\
\text { comprueba algo, texto alineado, Busca } \\
\text { en Cercaterm, compruebala } \\
\text { teminologia }[00: 18]\end{array}$} & & \\
\hline $10: 05$ & $\begin{array}{l}\text { El chico le da una solución provisional, sale } \\
{[00: 05]}\end{array}$ & & & & & & \\
\hline
\end{tabular}

Figure 4.3. Direct observation field notes transcribed in a Word table (Kuznik, 2010:545, Appendix 18. Direct observation and field notes. Company VIOLET) [page 97 in published version]

(3) Creating text files. A separate text file was created for each item of collected material. An analysis project was then opened in EdEt. The files were uploaded to the program, the informants were established and their properties were defined to control case and participant variability. Statements were assigned to the respective informants. In the case of direct observation, each participant observed was taken as an informant. Instead of informants' statements, the field notes taken during observation were analyzed (Figure 4.4). 
This is a post-print version of the following paper published online $24^{\text {th }}$ of February, 2017:

KUZNIK, Anna; VERD, Joan Miquel; OLALLA-SOLER, Christian (2016) "Mixed methods, mixed tools. The use of computer software for integrated qualitative and quantitative analysis", Journal of Research Design and Statistics in Linguistics and Communication Science [JRDS], 3.1. (December 2016), pp. 76-109, DOI: 10.1558/irds.32360 , URI: https://journals.equinoxpub.com/index.php/JRDS/article/view/32360, special issue "Mixed Methods" guest-edited by Anna Kuznik and Joan Miquel Verd, ISSN: 2052-417X (Print), 20524188 (Online)

\begin{tabular}{|c|c|c|c|c|}
\hline Edit Coding Analysis & Renository & Helo & & \\
\hline \multirow{2}{*}{ Codes: $\quad \square$} & \multirow{23}{*}{$\begin{array}{l}839 \\
840 \\
841 \\
842 \\
843 \\
844\end{array}$} & \multirow{23}{*}{\multicolumn{2}{|c|}{$\begin{array}{l}\text { algo, lo compara con las hojas que tiene delante [00:10] 10:58 Se levanta } \\
\text { con las hojas y las enseña a la chica de enfrente, alumna de prácticas } \\
\text { [00:04] 11:02 Se sienta: lee y compara el texto en las hojas con el texto en } \\
\text { la pantalla [00:04] 11:06 Hace búsqueda de la terminología en Google, lee } \\
\text { textos en Google [00:06] 11:12 Corrige cosas en el documento, trabaja con } \\
\text { el documento abierto, hace búsquedas en Google [00:11] 11:23 Entra una } \\
\text { chica y consulta algo mirando la pantalla, sale [00:01] 11:24 Comprueba la } \\
\text { terminologia en unas páginas web, revisa en la pantalla un documento } \\
\text { traducido (carta de un banco) [00:06] 11:30 Revisa la terminología en } \\
\text { Google [00:07] 11:37 Revisa un texto continuo, otra carta, hace consultas } \\
\text { terminológicas por Internet (Google) [00:18] 11:55 Sale con un papelito en } \\
\text { la mano y va a consultar algo en la sala de al lado [00:02] 11:57 Vuelve, } \\
\text { coge algunas hojas y comenta algo con Trad_2_AZUL, le pregunta } \\
\text { detalles, consulta significado de una frase en la hoja, consulta expresiones } \\
\text { en EN [00:03] 12:00 Sale a la cocina o lavabo [00:01] 12:01 Vuelve a } \\
\text { trabajar con la pantalla, corrige algo subrayado en verde en un programa } \\
\text { electrónico [00:05] 12:06 Entra una chica y comenta algo relacionado con } \\
\text { las hojas que trae de la sala de al lado; revisan algo juntas en la pantalla } \\
\text { [00:02] 12:08 Vuelve a trabajar sola en la pantalla, corrige y revisa [00:16] } \\
\text { 12:24 Entra otra chica, le comunica algo, hacen un proyecto juntas, sale } \\
\text { [00:01] 12:25 Vuelve a corregir el texto con colores en la pantalla [00:03] } \\
\text { 12:28 Entra una chica, hablan, intercambian opiniones y toman una } \\
\text { decisión común en materia de un encargo concreto [00:02] 12:30 Sale a } \\
\text { hablar algo con la misma chica en la sala de al lado [00:01] 12:31 Vuelve y } \\
\text { se sienta, sigue corrigiendo y traduciendo en un programa de TAO [00:44] } 1 \\
\text { 3:15-13:30 Teclea mucho, sigue trabajando con el mismo programa } \\
\end{array}$}} & \multirow{18}{*}{$\begin{array}{l}\text { Actividades servicio de t } \\
\text { Revisión. } \\
\text { Ausencia fuera de sala, } \\
\text { Hablar con compañero, } \\
\text { Actividades interacción, } \\
\text { Interacción con persona } \\
\text { Anécdotas/Risa, } \\
\text { Gestión, } \\
\text { Gestión de ficheros/pros } \\
\text { Trabajos terminológicos } \\
\text { Gestión hojas papel, } \\
\text { Atención alumnos de pr. } \\
\text { Ámbito socioprofesional } \\
\text { Consultas terminológica } \\
\text { Hacer una actividad jun1 } \\
\text { Consensuar actitud com }\end{array}$} \\
\hline & & & & \\
\hline$\Gamma$ Fold & & & & \\
\hline \multirow{6}{*}{\begin{tabular}{|l|} 
Reducción de plantilla \\
2.- Proceso de trabajo \\
+. Certificaciones \\
Explicitación del proceso \\
Alteraciones en el proceso \\
Asociaciones empresas \\
Lo que queda en la empresa
\end{tabular}} & & & & \\
\hline & & & & \\
\hline & & & & \\
\hline & & & & \\
\hline & & & & \\
\hline & & & & \\
\hline$::$ \{queries\} :: & & & & \\
\hline & & & & \\
\hline & & & & \\
\hline Persons: & & & & \\
\hline $\begin{array}{l}\text { Al_13_ANIL } \\
\text { Al_2_MIOLETA }\end{array}$ & & & & \\
\hline 11 & & & & \\
\hline & & & & \\
\hline & & & & \\
\hline \begin{tabular}{|ll} 
Al_13_ANIL_bc.txt & Al_2_V. \\
Al_13_ANIL_cont.txt & Al_2_V.
\end{tabular} & & & & \\
\hline 4 & & & & \\
\hline Graphic files: & & & & \\
\hline & & & & \\
\hline & & & & Plantilla, \\
\hline & & & & $\begin{array}{l}\text { Actividades interacción, } \\
\text { Interacción con persona }\end{array}$ \\
\hline
\end{tabular}

Figure 4.4. EdEt project displaying direct observation analysis, with activity duration quantified in the format hh:mm [page 97 in published version]

[page 98 in published version:]

The study's overall methodological approach was qualitative and abductive (Kuznik, 2010:231--232). Data on the duration of each translator's activities was only quantified in the case of direct observation. This quantification was not possible in $E d E t$. To quantify all the activities in terms of minutes, the researcher therefore entered the individual duration times in a separate Excel file. The total time for all the activities was 240 minutes, corresponding to 4 hours of direct observation (Figure 4.5., row data). 
KUZNIK, Anna; VERD, Joan Miquel; OLALLA-SOLER, Christian (2016) "Mixed methods, mixed tools. The use of computer software for integrated qualitative and quantitative analysis", Journal of Research Design and Statistics in Linguistics and Communication Science [JRDS], 3.1. (December 2016), pp. 76-109, DOI: 10.1558/irds.32360 , URI: https://journals.equinoxpub.com/index.php/JRDS/article/view/32360 , special issue "Mixed Methods" guest-edited by Anna Kuznik and Joan Miquel Verd, ISSN: 2052-417X (Print), 20524188 (Online)

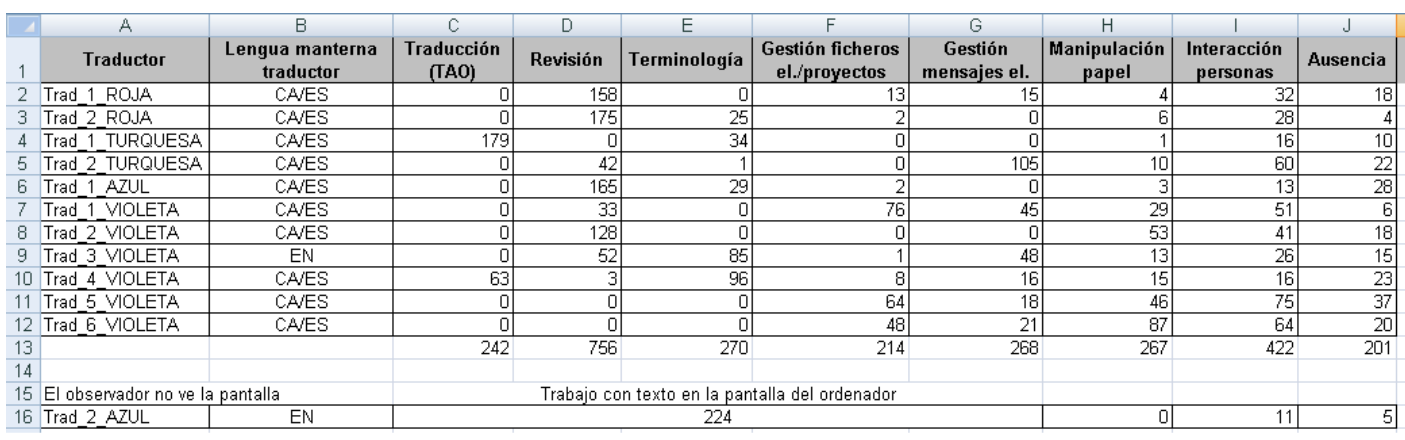

Figure 4.5. Quantification, in minutes, of translator activity duration (Kuznik, 2010:353, and CD-ROM) [page 98 in published version]

To discretely classify certain activities undertaken simultaneously and some that lasted less than a minute (particularly management activities and interaction with people), it was necessary to interpretatively identify primary activities, which were included in the quantification, and secondary activities, which were not.

The quantification of activities carried out by translators was displayed firstly in a more analytical level, per individual translator observed (Figure 4.6), and then in a more synthetic level, per group of translators (Figure 4.7).

The quantitative data was subsequently reduced to activity types such as computer-based activity, work with paper, interaction with people and instances of leaving the room (Figure 4.8.).

\subsection{Exploring methodological and technical limits}

In our experience (Kuznik 2010, Kuznik 2015, Kuznik and Little in press), EdEt has the following strong points:

- It is user-friendly and, at least when working with textual data only, it does not crash.

- Its interface is available in three languages, Polish, English and Spanish (the Help file is in Polish and Spanish only).

- It is compatible with a wide variety of data sources and textual data types, facilitating triangulation and the application of the same analysis codes to all the data involved (conceptual consistency in qualitative analysis). It allows for the integration of collected material.

[page 99 in published version:] 
KUZNIK, Anna; VERD, Joan Miquel; OLALLA-SOLER, Christian (2016) "Mixed methods, mixed tools. The use of computer software for integrated qualitative and quantitative analysis", Journal of Research Design and Statistics in Linguistics and Communication Science [JRDS], 3.1. (December 2016), pp. 76-109, DOI: 10.1558/irds.32360 , URI: https://journals.equinoxpub.com/index.php/JRDS/article/view/32360 , special issue "Mixed Methods" guest-edited by Anna Kuznik and Joan Miquel Verd, ISSN: 2052-417X (Print), 20524188 (Online)

- It is flexible in terms of coding. A single statement can be assigned to different codes at the same time (cases of overlapping codes are not penalized).

- It makes performing queries simple, and offers flexibility and variety for query criteria.

- It is ergonomic. It is always possible to see the fragments of text that have been coded and the codes that have been applied to them (a function added to later versions of the program). While there are few colors for highlighting, they are sufficient and easy on the eye.

- Its settings can be adapted to the specific needs of a researcher or project (a strong point of all CAQDAS programs).

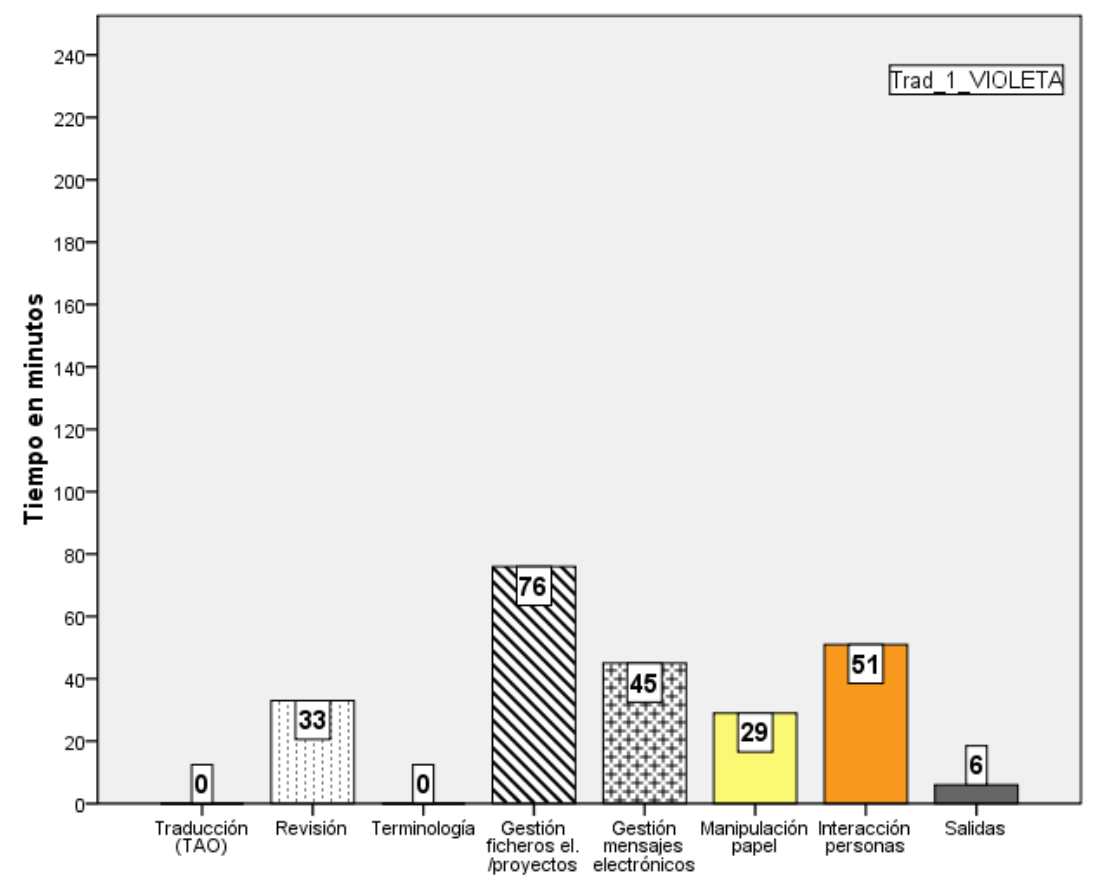

Figure 4.6. Quantification, in minutes, of translator activity duration (Trad_1_VIOLETA) in the company VIOLET (Kuznik, 2010:358) [page 99 in published version]

$E d E t$ also has certain limits, however. The main ones are the following:

- When fragments coded with selected codes or query results are exported from an $E d E t$ project to a separate txt file, neither the codes selected nor the query criteria are exported to or saved in the file. It is 
This is a post-print version of the following paper published online $24^{\text {th }}$ of February, 2017:

KUZNIK, Anna; VERD, Joan Miquel; OLALLA-SOLER, Christian (2016) "Mixed methods, mixed tools. The use of computer software for integrated qualitative and quantitative analysis", Journal of Research Design and Statistics in Linguistics and Communication Science [JRDS], 3.1. (December 2016), pp. 76-109, DOI: 10.1558/irds.32360 , URI: https://journals.equinoxpub.com/index.php/JRDS/article/view/32360 , special issue "Mixed Methods" guest-edited by Anna Kuznik and Joan Miquel Verd, ISSN: 2052-417X (Print), 20524188 (Online)

[page 100 in published version:]

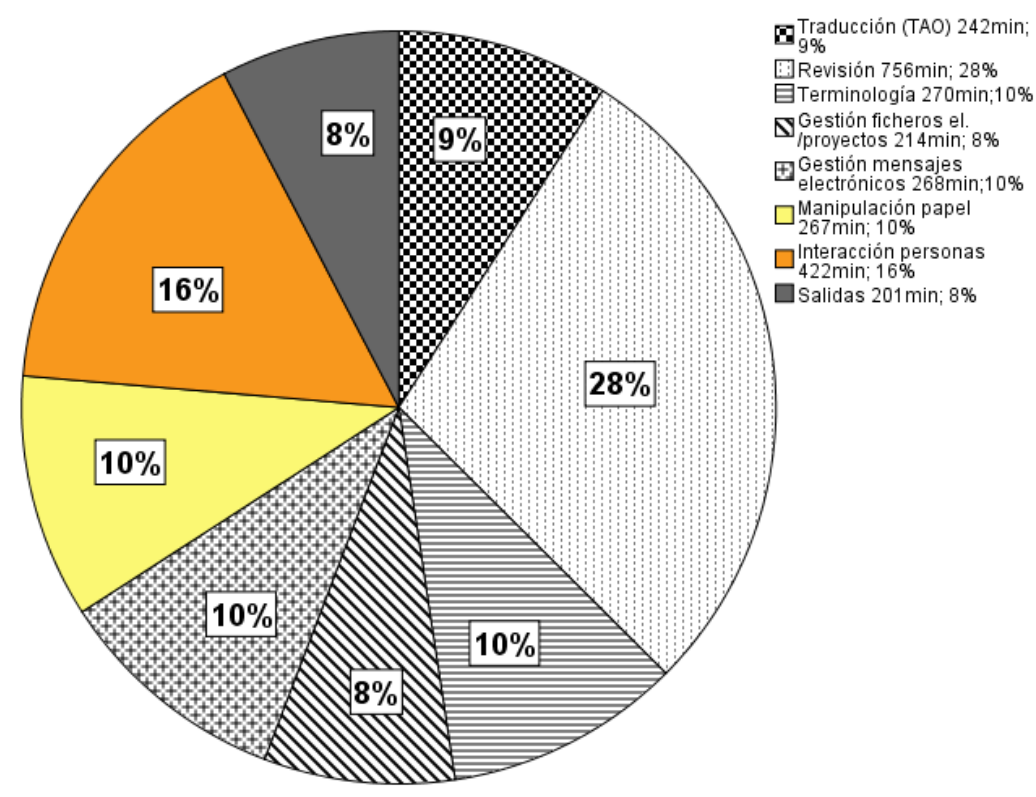

Figure 4.7. Distribution, in percentages, of translators' activities in ten translation companies (Kuznik, 2010:354) [page 100 in published version]

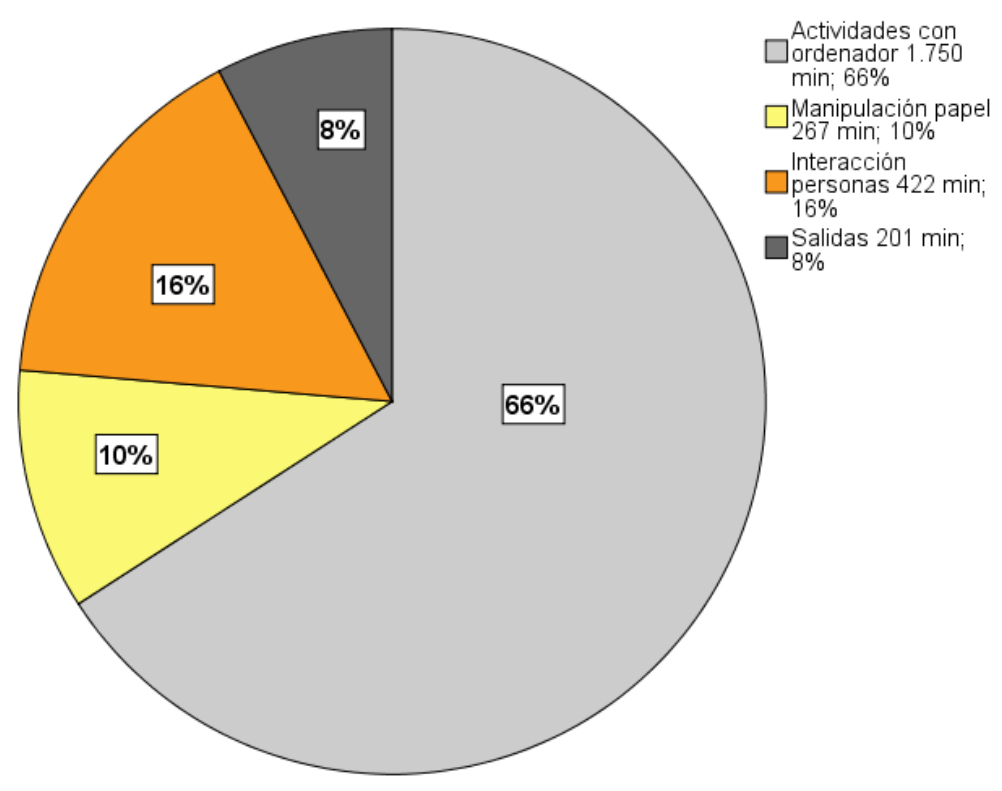


KUZNIK, Anna; VERD, Joan Miquel; OLALLA-SOLER, Christian (2016) "Mixed methods, mixed tools. The use of computer software for integrated qualitative and quantitative analysis", Journal of Research Design and Statistics in Linguistics and Communication Science [JRDS], 3.1. (December 2016), pp. 76-109, DOI: 10.1558/irds.32360 , URI: https://journals.equinoxpub.com/index.php/JRDS/article/view/32360 , special issue "Mixed Methods" guest-edited by Anna Kuznik and Joan Miquel Verd, ISSN: 2052-417X (Print), 20524188 (Online)

Figure 4.8. Distribution, in percentages, of translators' activities reduced to activity types in ten translation companies (Kuznik, 2010:355) [page 100 in published version]

[page 101 in published version:]

thus always necessary to include such information manually to avoid losing it. Additionally, .txt files containing exported results do not specify informants' names (there is no way of knowing to whom a statement corresponds unless the researcher has recorded this information in another way) or the numbers of the lines from which quotes (exported fragments) come.

- The code tree does not provide a spatial view of the codes and their relationships, hindering creative conceptual work (the only relationship reflected is the code tree's structure).

- There is no language correction function. Linguistic errors in texts are not automatically detected or corrected, and thus often remain present in final exported results if the researcher does not check the data previously.

\subsection{Potential for integrating qualitative and quantitative analysis}

As shown in section 4.2, researchers mainly use EdEt for qualitative analysis and few use it to begin to quantify data. It is only possible to begin data quantification if numerical values (times in hours and minutes, in the case of the study presented in section 4.2.2) are recorded in EdEt in text form rather than as quantifiable figures. In the quantification procedure, actual quantification has to be performed in other software (e.g. Excel). Quantitative data (recorded in EdEt in text form) cannot be automatically exported to another program as quantifiable figures, to guarantee the reliability of such data and minimize errors when they are transferred between two programs. Even if quantitative data is coded as an analysis category and then exported from an EdEt project, they are exported in .txt file format, offering little scope for adaptation to quantitative analysis programs. We can therefore conclude that its potential for mixed method analysis is tapped only when it is combined with other tools designed for quantitative analysis. EdEt is useful for formalizing qualitative data, but other software is needed to fully develop a quantitative translation. 
KUZNIK, Anna; VERD, Joan Miquel; OLALLA-SOLER, Christian (2016) "Mixed methods, mixed tools. The use of computer software for integrated qualitative and quantitative analysis", Journal of Research Design and Statistics in Linguistics and Communication Science [JRDS], 3.1. (December 2016), pp. 76-109, DOI: 10.1558/irds.32360 , URI: https://journals.equinoxpub.com/index.php/JRDS/article/view/32360 , special issue "Mixed Methods" guest-edited by Anna Kuznik and Joan Miquel Verd, ISSN: 2052-417X (Print), 20524188 (Online)

\section{$5 \quad$ Final reflections and conclusions}

In this paper we have presented two software programs that are not widely known among the scientific community: Camtasia, which records the computer screen activity of the participants studied, and $E d E t$, which organizes qualitative data recorded by other means and allows qualitative content analysis. We have presented their general features and functions and the main studies carried out with these programs in the field of translation studies and cultural studies. With this review of empirical studies and different ways of using Camtasia and EdEt software, we have offered an exemplification of their

[page 102 in published version:]

application to concrete research situations. We have complemented these exemplifications by presenting in detail the main technical issues related to their use in our own research experience. We have focused on the methodological and technical advantages and limitations of the software. Finally, we have discussed the possibilities that these programs offer for addressing the integration of qualitative and quantitative data, particularly when this integration is done by means of a quantitative translation. All these insights can help other researchers decide whether to use these or similar programs in their own research projects, according to their research objectives, the type of data they are working with and the type of analysis they wish to carry out.

Although software designed to carry out data conversion completely is now available (Fielding, 2012), we have focused on two programs that carry out this process only partially, leaving an important role to the procedures developed by means of other analytical tools, always, of course, under the interpretive control of the analysts. Camtasia and EdEt play a different role in the research process: Camtasia is for data collection, while EdEt is for data analysis. However, in the examples of research that have been reviewed in this paper, both programs have helped significantly in the process of quantitative translation of qualitative data. In the case of Camtasia, the possibility of thoroughly identifying the great variety of actions carried out by translators and recording the time spent on these actions provided a preliminary quantitative overview of the performance of translators that could be easily connected with the categorical coding of the on-screen activity. The role of EdEt was more modest, and it was important mostly in the qualitative stage of the analysis. Nevertheless, the possibility of obtaining a digital record of all the qualitative information obtained during the fieldwork allowed a better quantitative translation, 
KUZNIK, Anna; VERD, Joan Miquel; OLALLA-SOLER, Christian (2016) "Mixed methods, mixed tools. The use of computer software for integrated qualitative and quantitative analysis", Journal of Research Design and Statistics in Linguistics and Communication Science [JRDS], 3.1. (December 2016), pp. 76-109, DOI: 10.1558/irds.32360 , URI: https://journals.equinoxpub.com/index.php/JRDS/article/view/32360 , special issue "Mixed Methods" guest-edited by Anna Kuznik and Joan Miquel Verd, ISSN: 2052-417X (Print), 20524188 (Online)

compared with a situation in which no software is used for the qualitative stage. The Excel program was used to perform this quantification, but the analysis with EdEt was an indispensable step for obtaining a precise and unbiased quantitative recording of all the information used in the research.

Even if these programs are used only in some stages of the whole process, the advantages of using them for the integrated analysis of qualitative and quantitative data are fairly evident. Below we reassess the criticisms raised in section 2 in light of our experience in the use of Camtasia and EdEt in mixed methods research.

With respect to the methodological criticisms, our experience with Camtasia and $E d E t$ shows that their use does not produce a lack of interpretation in the analysis because the data was not coded automatically with the software. Also, we do not consider automatic content analysis software suitable for the quantitizing strategy, because this kind of software is unable to assign different codes to polysemic words or to distinguish between different meanings

[page 103 in published version:]

of the same terms in different sentences. This is why the first stage of coding was based on a human interpretation of qualitative material. When software is used to record analyst's interpretations, the use of computers to perform the analysis makes the analyst's interpretation transparent and explicit. Regarding the criticism that the use of software implies a loss of control by the analyst, our experience with Camtasia and $E d E t$ shows that they only offer the researcher tools for managing data in the way he/she considers appropriate. In fact, the researcher has to take control of the procedure and decide what methods and tools are to be used in the analysis, because the computer does not process the information by itself. As for the criticism of excessive formalization of the analysis, our experience using Camtasia and EdEt shows that the degree of formalization is decided by the researcher who uses the program. Though the ease of use of certain tools can lead to abuse (e.g. coding, which can be done with a couple of 'clicks' with the computer mouse), this is not due to the software but rather to inappropriate use.

With respect to the epistemological criticisms raised in section 2, and more concretely the supposed forced imposition of categories for the analysis, our experience using Camtasia and EdEt shows that these programs do not predefine analytical categories in any way: it is the researcher's duty to design, test and apply his/her own categories. In relation to the charge of leaving aside the extra-textual dimensions of data, our experience shows that the use of computer software does not prevent the 
KUZNIK, Anna; VERD, Joan Miquel; OLALLA-SOLER, Christian (2016) "Mixed methods, mixed tools. The use of computer software for integrated qualitative and quantitative analysis", Journal of Research Design and Statistics in Linguistics and Communication Science [JRDS], 3.1. (December 2016), pp. 76-109, DOI: 10.1558/irds.32360 , URI: https://journals.equinoxpub.com/index.php/JRDS/article/view/32360 , special issue "Mixed Methods" guest-edited by Anna Kuznik and Joan Miquel Verd, ISSN: 2052-417X (Print), 20524188 (Online)

contextual and social information from being taken into account in the interpretation. It was our job to interpret and translate into categories the extra-textual information that was relevant in order to fully understand the information collected. Finally, the idea that computer programs conceal the role of the researcher as an 'active agent' in the analysis does not apply to our research. Our experience illustrates that since there are no unique interpretations in qualitative analysis, it was important to show how the researcher 'read' the data. In this respect, EdEt was especially useful as it allowed us to use its analytical tools to reflect on our own interpretations, and the codes could be stored and retrieved later on for a reflexive re-analysis and review.

Summing up, methodological and epistemological criticisms of the use of computer software for analyzing qualitative data and performing quantitative translation of this data have focused on the instruments rather than on the way researchers use them. These criticisms are not based on the use of computer software, but rather on its misuse. A wide range of tools are available for facilitating the analysis and quantification of qualitative data. If researchers use these tools appropriately, it should not result in an absence of interpretation, a loss of control, or even an over-formalization of the analysis. In fact, the researcher's interpretation of data might become the core of the analysis

[page 104 in published version:]

process: it is not the computer that defines the categories applied to data or the development of the analysis but rather the researcher, who is able to participate actively in this process by designing, testing and applying categories based on human interpretation of the data. If researchers learn to use this software appropriately for the collection and analysis of qualitative data, it will benefit research and the scientific community.

\section{About the authors}

[pages 104-105 in published version:]

Anna Kuznik is a graduate in French Studies from the Jagiellonian University of Cracow (Uniwersytet Jagielloński w Krakowie) in Poland, she was awarded a European $\mathrm{PhD}$ in Translation and Intercultural Studies by the Autonomous University of Barcelona (Universitat Autònoma de Barcelona) in Spain. A member of the PACTE research group since 2005, she has worked in the Department of Romance Studies (Instytut Filologii Romańskiej) of the University of Wrocław (Uniwersytet Wrocławski) 
KUZNIK, Anna; VERD, Joan Miquel; OLALLA-SOLER, Christian (2016) "Mixed methods, mixed tools. The use of computer software for integrated qualitative and quantitative analysis", Journal of Research Design and Statistics in Linguistics and Communication Science [JRDS], 3.1. (December 2016), pp. 76-109, DOI: 10.1558/irds.32360 , URI: https://journals.equinoxpub.com/index.php/JRDS/article/view/32360 , special issue "Mixed Methods" guest-edited by Anna Kuznik and Joan Miquel Verd, ISSN: 2052-417X (Print), 20524188 (Online)

in Poland since 2011. Certified translator of French and Spanish in Poland. Recent papers: 'La traduction comme travail: perspectives croisées en ergonomie, sociologie et traductologie' (ILCEA [En Ligne], 27/2016, 16 pages); 'Work content of in-house translators in small and medium-sized industrial enterprises. Observing real work situations' (JoSTrans. The Journal of Specialised Translation 25, January 2016, $213-$ 231); and 'How to define good professional translators and interpreters: Applying the behavioural approach to studying competences in the field of translation studies' (Across Languages and Cultures 16 (1), 1-27, 2015, with Amparo Hurtado Albir).

Joan Miquel Verd is Associate Professor in the Department of Sociology at the Autonomous University of Barcelona (Universitat Autònoma de Barcelona, UAB). Doctor in Sociology (2002). He is BA in Business and Economics (1996) and BA in Political Science and Sociology (1994). He is the director of the Centre for Sociological Research on Daily Life and Work (Centre d'Estudis Sociologics sobre la Vida Quotidiana i el Treball - QUIT) since 2013 and member of the Institute for Labor Studies (IET) since its founding in 2011. His main research interests are the analysis of social networks, youth labour trajectories and the connections between social protection and employment. Methodologically his work focuses on qualitative text analysis, mixed methods and computer assisted qualitative data analysis. His most recent publications are the book (2016) Introduccion a la investigacion cualitativa. Fases metodos y tecnicas (with Carlos Lozares), published by Síntesis and the article (2016) 'Employment instability and economic crisis in Spain: What are the elements that make a difference in the trajectories of younger adults?' (with Martí López-Andreu), published in European Societies.

Christian Olalla-Soler earned a Degree in Translation and Interpreting at the Universitat Autònoma de Barcelona and in Teaching of Spanish as a Foreign Language at the University of Valencia. He is currently working on his $\mathrm{PhD}$ dissertation entitled 'Translator's cultural competence and its acquisition'. Since 2012 he has been a member of the research group PACTE (Process of Acquisition of Translation Competence and Evaluation). His research interests come within the following fields: translator and interpreter training, interculturality and ideology, cognitive processes in translation and interpreting, and empirical research methodology in translation and interpreting studies. He is member of the European Association of Methodology. Recent publications: 'Procedures for assessing the acquisition of cultural competence in translator training' (The Interpreter and Translator Trainer, with Amparo Hurtado Albir, 2016, 10 (3), 1-25), 'Más allá del aula: El papel de la Asociación Espanola Universitaria de Traductores e Intérpretes en Formación' (Onomazein, 2015, 31 (1), 5265), and 'An experimental study into the acquisition of cultural competence in translator training. Research design and methodological issues' (Translation and Interpreting, 2015, 7 (1), 86-110). 
KUZNIK, Anna; VERD, Joan Miquel; OLALLA-SOLER, Christian (2016) "Mixed methods, mixed tools. The use of computer software for integrated qualitative and quantitative analysis", Journal of Research Design and Statistics in Linguistics and Communication Science [JRDS], 3.1. (December 2016), pp. 76-109, DOI: 10.1558/irds.32360 , URI: https://journals.equinoxpub.com/index.php/JRDS/article/view/32360 , special issue "Mixed Methods" guest-edited by Anna Kuznik and Joan Miquel Verd, ISSN: 2052-417X (Print), 20524188 (Online)

\section{References}

[pages 105-109 in published version:]

Bazeley, P. (2010) Computer-assisted integration of Mixed Methods data sources and analyses. In A. Tashakkori and Ch. Teddlie (eds) SAGE Handbook of Mixed Methods in Social and Behavioral Research 431--467. Thousand Oaks, California: Sage. $2^{\text {nd }}$ Edition.

Berelson, B. (1971) Content Analysis in Communication Research. New York: Hafner Publishing Company.

Bericat, E. (1998) La integración de los métodos cuantitativo y cualitativoen la investigación social. Barcelona: Ariel.

Bieliński, J., Iwińska, K. and Rosińska-Kordasiewicz, A (2007) Analiza danych jakościowych przy użyciu programów komputerowych. ASK 16: 89--114.

Blaikie, N.W.H. (1991) A critique of the use of triangulation in social research. Quality and Quantity 25: 115--136.

Boyatzis, R.E. (1998)Transforming Qualitative Information: Thematic Analysis and Code Development. Thousand Oaks, California: Sage.

Creswell, J.W. and Plano-Clark, V.L. (2011) Designing and Conducting Mixed Methods Research. Thousand Oaks, California: Sage. $2^{\text {nd }}$ Edition.

Denzin, N. K. and Lincoln, Y. S (2011) "Introduction. The discipline and practice of qualitative research". In Norman K. Denzin and Yvonna S. Lincoln: The Sage Handbook of Qualitative Research. 1--19 Thousand Oaks, California: Sage.

Ehrensberger-Dow, M. and Massey, G. (2008) Exploring translation competence by triangulating empirical data. Norwich Papers 16: 1--20.

Ehrensberger-Dow, M. and Massey, G. (2014) Cognitive ergonomic issues in professional translation. In J.W. Schwieter and A. Ferreira (eds) The development of translation competence: theories and methodologies from psycholinguistics and cognitive science 58--86. Cambridge: Cambridge Scholars Publishing.

Fàbregues, S. (2015) La conceptualización y operacionalización de la calidad de la investigación basada en métodos mixtos. Un estudio de casos múltiples de cuatro disciplinas. Doctoral thesis. Departamento de Sociología. Universidad Autónoma de Barcelona.

Fielding, J. and Fielding, N. (2008) Synergy and synthesis: integrating qualitative and quantitative data. In P. Alasuutari, L. Bickman and J. Brannen (eds) The SAGE Handbook of Social Research Methods 555--571. Thousand Oaks, California: Sage.

Fielding, N. (2012) Triangulation and Mixed Methods designs: Data integration with new research technologies. Journal of Mixed Methods Research 6(2): 124--136.

García-Álvarez, E., López-Sintas, J. and Samper-Martínez, A. (2015)The Social Network Gamer's Experience of Play: A Netnography of Restaurant City on 
KUZNIK, Anna; VERD, Joan Miquel; OLALLA-SOLER, Christian (2016) "Mixed methods, mixed tools. The use of computer software for integrated qualitative and quantitative analysis", Journal of Research Design and Statistics in Linguistics and Communication Science [JRDS], 3.1. (December 2016), pp. 76-109, DOI: 10.1558/irds.32360 , URI: https://journals.equinoxpub.com/index.php/JRDS/article/view/32360 , special issue "Mixed Methods" guest-edited by Anna Kuznik and Joan Miquel Verd, ISSN: 2052-417X (Print), 20524188 (Online)

Facebook. Games and Culture 20: 1--21.

Gibbs, G. R. (2007) Media Review: Atlas.ti Software to Assist With the Qualitative Analysis of Data. Journal of Mixed Methods Research 1: 103--104. DOI: $10.1177 / 2345678906291490$

Giozza, M. (2013) La investigación en traducción orientada al proceso. LyCE Estudios 6: 93--118.

Hurtado Albir, A. (in press) (ed.) Researching Translation Competence by PACTE Group. Amsterdam: John Benjamins.

Kaliszewska, I. (2009) Wspomagana komputerowo analiza wywiadów etnograficznych i tekstów folkloru. In P. Grochowski and G. Gańcarczyk (eds) Folklor w dobieInternetu 197--203. Toruń: Wydawnictwo Naukowe Uniwersytetu Mikołaja Kopernika.

Kaliszewska, I. (2008) Editor for Ethnographers (EdEt) and Advanced Qualitative Queries (AQQ) (Power Point presentation). Workshop presented at SAIC 2008. Seminario avanzado de investigación cualitativa: Estrategias de diseño y análisis de datos, orgenised by Centre d'Estudis i de Recerca d'Humanitats de la Universitat Autònoma de Barcelona, led by Jordi López Sintas, Universitat Autònoma de Barcelona, 07-11/07/2008.

Koetting, J.R. (1984) Foundations of Naturalistic Inquiry: Developing a Theory Base for Understanding Individual Interpretations of Reality. Paper presented at the Annual Meeting of the Association for Educational Communications and Technology (Dallas, TX, January 20-24, 1984).

Kuznik, A. (in press) Use of Instrumental Resources. In A. Hurtado Albir (ed.) Researching Translation Competence by PACTE Group 219--241, Amsterdam: John Benjamins.

Kuznik, A. and Olalla-Soler, C. (in press) Results of PACTE Group's Experimental Research on Translation Competence Acquisition. The Acquisition of the Instrumental Sub-Competence. Across Languages and Cultures 19(1).

Kuznik, A. and Little, V. (in press) Domaines économiques et axes d'employabilité des philologues français et des traducteurs en Pologne. Méta: journal des traducteurs, 62(1).

Kuznik, A. (2015) Étudiants polonais de langue et civilisation françaises et leur avenir professionnel. In E. Skibińska, R. Solová and K. Gostkowska (eds) Vingt cinq ans après... Traduire dans une Europe en reconfiguration 289--309. Paris: Orizons.

Kuznik, A. (2010) El contenido de los puestos de trabajo de los traductores. El caso de los traductores internos en las empresas de traducción de Barcelona, Doctoral thesis. Universitat Autònoma de Barcelona, URI TDX: $<$ http://tdx.cat/handle/10803/5279> (published version 2012. Saarbrücken: AV Akademikerverlag GmbH \& Co. KG/ Editorial Académica Española).

Lincoln, Y.S. and Guba, E.G. (1985) Naturalistic inquiry. Berverly Hills, California: Sage. 
KUZNIK, Anna; VERD, Joan Miquel; OLALLA-SOLER, Christian (2016) "Mixed methods, mixed tools. The use of computer software for integrated qualitative and quantitative analysis", Journal of Research Design and Statistics in Linguistics and Communication Science [JRDS], 3.1. (December 2016), pp. 76-109, DOI: 10.1558/irds.32360 , URI: https://journals.equinoxpub.com/index.php/JRDS/article/view/32360 , special issue "Mixed Methods" guest-edited by Anna Kuznik and Joan Miquel Verd, ISSN: 2052-417X (Print), 20524188 (Online)

López-Sintas, J., Rojas de Francisco, L. and García-Álvarez, E. (2015) The Nature of Leisure Revisited: An Interpretation of Digital Leisure. Journal of Leisure Research. 47(1): 79--101.

Mertens, Donna M.; Bazeley, Pat; Bowleg, Lisa; Fielding, Nigel; Maxwell, Joseph; Molina-Azorin, J.F. and Niglas, K. (2016) The Future of Mixed Methods: A Five Year Projection to 2020. Mixed Methods International Research Association [Retrieved on 16 October 2016 fromhttps://mmira.wildapricot.org].

Miles, M.B. and Huberman, A.M. (1994) Qualitative Data Analysis. An Expanded Sourcebook. Thousand Oaks, California: Sage. $2^{\text {nd }}$ Edition.

Olalla-Soler, C. (2015) An experimental study into the acquisition of cultural competence in translator training: Research design and methodological issues. The International Journal for Translation \& Interpreting Research 7(1): 86-110.

Onwuegbuzie, A.J. and Teddlie, C. (2003) A Framework for Analyzing Data in Mixed Methods Research. In A. Tashakkori and C. Teddlie (eds) Handbook of Mixed Methods in Social and Behavioral research 351--383. Thousand Oaks, California: Sage.

PACTE (2001) La Competencia traductora y su adquisición. Quaderns. Revista de Traducció 6: 39--45 (authors in alphabetical order: A.Beeby, L.Berenguer, D.Ensinger, O.Fox, A.Hurtado Albir, N.Martínez Melis, W.Neunzig, M.Orozco, M.Presas; principal researcher: A.Hurtado Albir).

PACTE (2002a) Una investigación empírico-experimental sobre la adquisición de la competencia traductora. In A. Alcina Caudet and S. Gamero Pérez (eds) $L a$ traducción científico-técnica y la terminología en la sociedad de la información, 125--138. Castellón de la Plana: Publicacions de la Universitat Jaume I (authors in alphabetical order: A.Beeby, M.Fernández, O.Fox, A.Hurtado Albir, N.Martínez Melis, W.Neunzig, M.Orozco, M.Presas, P.Rodríguez-Inés; principal researcher: A.Hurtado Albir).

PACTE (2002b) Exploratory tests in a study of translation competence. Conference Interpretation and Translation 4(2): 41--69 (authors in alphabetical order: A.Beeby, M.Fernández, O.Fox, A.Hurtado Albir, W.Neunzig, M.Orozco, M.Presas, P.Rodríguez-Inés, L.Romero; principal researcher: A.Hurtado Albir).

PACTE (2003) Building a Translation Competence Model. In A. Fabio (ed.) Triangulating Translation: Perspectives in process oriented research 43-66. Amsterdam: John Benjamins (authors in alphabetical order: A.Beeby, M.Fernández, O.Fox, A.Hurtado Albir, W.Neunzig, M.Presas, P.Rodríguez-Inés. L.Romero; principal researcher: A.Hurtado Albir).

PACTE (2005a) Primeros resultados de un experiment sobre la Competencia Traductora. In Actas del II Congreso Internacional de la AIETI (Asociación Ibérica de Estudios de Traducción e Interpretación) 'Información y documentación' 573--587. Madrid: Publicaciones de la Universidad Pontificia Comillas (authors in alphabetical order: A.Beeby, M.Fernández, O.Fox, 
KUZNIK, Anna; VERD, Joan Miquel; OLALLA-SOLER, Christian (2016) "Mixed methods, mixed tools. The use of computer software for integrated qualitative and quantitative analysis", Journal of Research Design and Statistics in Linguistics and Communication Science [JRDS], 3.1. (December 2016), pp. 76-109, DOI: 10.1558/irds.32360 , URI: https://journals.equinoxpub.com/index.php/JRDS/article/view/32360 , special issue "Mixed Methods" guest-edited by Anna Kuznik and Joan Miquel Verd, ISSN: 2052-417X (Print), 20524188 (Online)

A.Hurtado Albir, I.Kozlova, W.Neunzig, M.Presas, P.Rodríguez-Inés, L.Romero; principal researcher: A.Hurtado Albir).

PACTE (2005b) Investigating Translation Competence: Conceptual and Methodological Issues. Meta 50(2): 609--619 (authors in alphabetical order: A.Beeby, M.Fernández, O.Fox, A.Hurtado Albir, I.Kozlova, W.Neunzig, M.Presas, P.Rodríguez-Inés, L.Romero; principal researcher: A.Hurtado Albir).

PACTE (2008) First results of a Translation Competence Experiment: 'Knowledge of Translation' and 'Efficacy of the Translation Process'. In J. Kearns (ed.) Translator and Interpreter Training. Issues, Methods and Debates 104-126, London: Continuum (authors in alphabetical order: A.Beeby, M.Fernández, O.Fox, A.Hurtado Albir, I.Kozlova, A.Kuznik, W.Neunzig, P.Rodríguez-Inés. L.Romero; principal researcher: A.Hurtado Albir).

PACTE (2014) First Results of PACTE Group's Experimental Research on Translation Competence Acquisition: The Acquisition of Declarative Knowledge of Translation. MonTI. Monografías de Traducción e Interpretación special issue 1: 85--115 (authors in alphabetical order: A.Beeby, L.Castillo, O.Fox, A.GalánMañas, A.Hurtado Albir, A.Kuznik, G.Massana, W.Neunzig, C.Olalla-Soler, P.Rodríguez-Inés, L.Romero, M.Taffarel, S.Wimmer; principal researcher: A.Hurtado Albir).

PACTE (2015) Results of PACTE's Experimental Research on the Acquisition of Translation Competence: The Acquisition of Declarative and Procedural Knowledge in Translation. The Dynamic Translation Index. Translation Spaces 4(1): 29-53 (authors in alphabetical order: A.Beeby, L.Castillo, O.Fox, A.GalánMañas, A.Hurtado Albir, A.Kuznik, G.Massana, W.Neunzig, C.Olalla-Soler, P.Rodríguez-Inés, L.Romero; principal researcher: A.Hurtado Albir).

PACTE (in press a) Developing the research design. In A. Hurtado Albir (ed.) Researching Translation Competence by PACTE Group 63--79. Amsterdam: John Benjamins (authors in alphabetical order: A.Beeby, O.Fox, A.Hurtado Albir, A.Kuznik, W.Neunzig, P.Rodriguez-Inés, L.Romero, S.Wimmer; principal researcher: A.Hurtado Albir).

PACTE (in press b) Experiment design. In A. Hurtado Albir (ed.) Researching Translation Competence by PACTE Group 81--96. Amsterdam: John Benjamins (authors in alphabetical order: A.Beeby, O.Fox, A.Hurtado Albir, A.Kuznik, W.Neunzig, P.Rodriguez-Inés, L.Romero, S.Wimmer; principal researcher: A.Hurtado Albir).

PACTE (in press c) Decision-making. In A. Hurtado Albir (ed.) Researching Translation Competence by PACTE Group 191--210. Amsterdam: John Benjamins (authors in alphabetical order: A.Beeby, O.Fox, A.Hurtado Albir, A.Kuznik, W.Neunzig, P.Rodriguez-Inés, L.Romero, S.Wimmer; principal researcher: A.Hurtado Albir).

PACTE (in press d) Efficacy of the Translation Process. In A. Hurtado Albir (ed.) Researching Translation Competence by PACTE Group 211--218. Amsterdam: 
KUZNIK, Anna; VERD, Joan Miquel; OLALLA-SOLER, Christian (2016) "Mixed methods, mixed tools. The use of computer software for integrated qualitative and quantitative analysis", Journal of Research Design and Statistics in Linguistics and Communication Science [JRDS], 3.1. (December 2016), pp. 76-109, DOI: 10.1558/irds.32360 , URI: https://journals.equinoxpub.com/index.php/JRDS/article/view/32360 , special issue "Mixed Methods" guest-edited by Anna Kuznik and Joan Miquel Verd, ISSN: 2052-417X (Print), 20524188 (Online)

John Benjamins (authors in alphabetical order: A.Beeby, O.Fox, A.Hurtado Albir, A.Kuznik, W.Neunzig, P.Rodriguez-Inés, L.Romero, S.Wimmer; principal researcher: A.Hurtado Albir).

PACTE (in press e) Appendix VI. Decision-making. In A. Hurtado Albir (ed.) Researching Translation Competence by PACTE Group 373. Amsterdam: John Benjamins (authors in alphabetical order: A.Beeby, O.Fox, A.Hurtado Albir, A.Kuznik, W.Neunzig, P.Rodriguez-Inés, L.Romero, S.Wimmer; principal researcher: A.Hurtado Albir).

Tashakkori, A. and Teddlie, C. (1998) Mixed methodology. Combining quantitative and qualitative approaches. Thousand Oaks, California: Sage.

TREC (2015a) Home/Inicio. Retrieved on 24 October 2016 fromhttp://pagines.uab.cat/trec/

TREC (2015b) Resources/Recursos. Retrieved on 24 October 2016 fromhttp://pagines.uab.cat/trec/content/resources-recursos

TREC (2015c) MovEs II: Traducción y Creatividad [MovEs II: Translation and Creativity]. Retrieved on 24 October 2016

fromhttp://pagines.uab.cat/trec/content/moves-ii-traducci\%C3\%B3n-ycreatividad-moves-ii-translation-and-creativity

TREC (2015d) Conceptualización y evaluación de la creatividad en traducción: aplicaciones docentes y profesionales [Conceptualising and assessing translational creativity: teaching and professional implications]. Retrieved on 24 October 2016 from http://pagines.uab.cat/trec/content/conceptualizaci\%C3\%B3n-yevaluaci\%C3\%B3n-de-la-creatividad-en-traducci\%C3\%B3n-aplicacionesdocentes-y

Verd, J. M. and López, P. (2008) La eficiencia teórica y metodológica de los diseños multimétodo .Empiria. Revista de Metodología de Ciencias Sociales.16: 13--42.

Verd, J. M. and Lozares, C. (2016) Introducción a la investigación cualitativa. Fases, métodos y técnicas. Madrid: Síntesis.

Weber, R. P. (1985) Basic Content Analysis. Beverly Hills, California: Sage.

Notes [page 104 in published version:]

i Other similar software could have been chosen. We chose these programs because of the authors' experience with them. However, our reflections and conclusions can be generalized to other similar programs, as their characteristics are not especially idiosyncratic.

ii $A$ data conversion procedure from a quantitative form to a qualitative form is also possible, although it is less usual (Creswell and Plano-Clark, 2011:232).

iii http://pagines.uab.cat/trec/

iv http://grupsderecerca.uab.cat/pacte/en; PACTE: Procés d'Adquisició de la Competència

Traductora i Avaluació; Group publications can be found here:http://ddd.uab.cat/collection/pacte? $1 n=e n \& a s=1$ 
This is a post-print version of the following paper published online $24^{\text {th }}$ of February, 2017:

KUZNIK, Anna; VERD, Joan Miquel; OLALLA-SOLER, Christian (2016) "Mixed methods, mixed tools. The use of computer software for integrated qualitative and quantitative analysis", Journal of Research Design and Statistics in Linguistics and Communication Science [JRDS], 3.1. (December 2016), pp. 76-109, DOI: 10.1558/irds.32360 , URI: https://journals.equinoxpub.com/index.php/JRDS/article/view/32360, special issue "Mixed Methods" guest-edited by Anna Kuznik and Joan Miquel Verd, ISSN: 2052-417X (Print), 20524188 (Online)

vhttps://www.techsmith.com/morae.html

vic The analysis was performed with the help of the EdEt version.32-bit (Editor for Ethnographers, available from http://www.etnologia.uw.edu.pl/edet) software for computer aided qualitative data analysis." (García-Álvarez et al., 2015:6). 